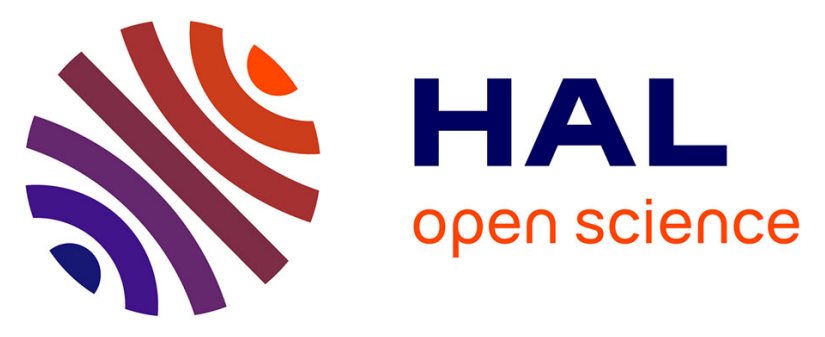

\title{
Mono- and Diplatinum Polyynediyl Complexes as Potential Push-Pull Chromophores: Synthesis, Characterization, TD-DFT Modeling, and Photophysical and NLO Properties
}

Sébastien Gauthier, Ariel Porter, Sylvain Achelle, Thierry Roisnel, Vincent

Dorcet, Alberto Barsella, Nicolas Le Poul, Patricia Guevara Level, Denis

Jacquemin, Françoise Robin-Le Guen

\section{- To cite this version:}

Sébastien Gauthier, Ariel Porter, Sylvain Achelle, Thierry Roisnel, Vincent Dorcet, et al.. Mono- and Diplatinum Polyynediyl Complexes as Potential Push-Pull Chromophores: Synthesis, Characterization, TD-DFT Modeling, and Photophysical and NLO Properties. Organometallics, 2018, 37 (14), pp.2231-2244. 10.1021/acs.organomet.8b00223 . hal-01834786

\author{
HAL Id: hal-01834786 \\ https://hal.univ-brest.fr/hal-01834786
}

Submitted on 20 Sep 2018

HAL is a multi-disciplinary open access archive for the deposit and dissemination of scientific research documents, whether they are published or not. The documents may come from teaching and research institutions in France or abroad, or from public or private research centers.
L'archive ouverte pluridisciplinaire $\mathbf{H A L}$, est destinée au dépôt et à la diffusion de documents scientifiques de niveau recherche, publiés ou non, émanant des établissements d'enseignement et de recherche français ou étrangers, des laboratoires publics ou privés. 


\section{Mono- and diplatinum polyynediyl complexes as potential push- pull chromophores: synthesis, characterization, TD-DFT modeling, photophysical and NLO properties}

Sébastien Gauthier, ${ }^{,}$a Ariel Porter, ${ }^{\mathrm{b}}$ Sylvain Achelle, ${ }^{\mathrm{a}}$ Thierry Roisnel, ${ }^{\mathrm{a}}$ Vincent Dorcet, ${ }^{\mathrm{a}}$ Alberto Barsella, ${ }^{\mathrm{c}}$ Nicolas Le Poul, ${ }^{\mathrm{d}}$ Patricia Guevara Level, ${ }^{\mathrm{e}}$ Denis Jacquemin, ${ }^{\mathrm{e}}$ and Françoise Robin-Le Guen ${ }^{\mathrm{a}}$

${ }^{\text {a } U n i v . ~ R e n n e s, ~ C N R S, ~ I S C R ~(I n s t i t u t ~ d e s ~ S c i e n c e s ~ C h i m i q u e s ~ d e ~ R e n n e s) ~-~ U M R ~ 6226, ~ F-~}$ 35000 Rennes, France. E-mail: sebastien.gauthier@univ-rennes1.fr, Tel:+33 296469344

${ }^{\mathrm{b}}$ Center of Natural Sciences, Northern Kentucky University, Nunn Drive, Highland Height, KY 41099, USA

${ }^{\mathrm{c}}$ Département d'Optique ultra-rapide et Nanophotonique, IPCMS-CNRS, 23 rue du Loess, BP 43, 67034 Strasbourg Cedex 2, France.

${ }^{\mathrm{d}}$ Laboratoire de Chimie, Électrochimie Moléculaires et Chimie Analytique, UMR CNRS 6521, Université de Bretagne Occidentale, UFR Sciences et Techniques, 6 avenue Victor Le Gorgeu - CS 93837, F-29238 Brest Cedex 3, France

e Laboratoire CEISAM - UMR CNRS 6230, Université de Nantes, 2 Rue de la Houssinière, BP 92208, F-44322 Nantes Cedex 3, France 


\begin{abstract}
This paper presents the syntheses, the photophysical and the electrochemical characterizations of four new mono- and diplatinum polyynediyl complex chromophores end-capped with diphenylpyranylidene and pentafluorophenyl moieties. The nonlinear optical properties (NLO) of these compounds is investigated using the Electric-Field-Induced Second Harmonic generation (EFISH) technique and their experimental optical properties are confirmed by Time-Dependent Density Functional Theory (TD-DFT) with a range-separated hybrid. All complexes show positive $\mu \beta$ values. While the inductive electron-withdrawing pentafluorophenyl ligand, the length of the polyyne linkers and the number of platinum centers do not seem to significantly affect the NLO responses of these complexes, their structural configuration plays a significant role, as shown by the V-shaped complex 10 exhibiting the highest $\mu \beta$ value of the series of complexes, twice as high as that of the linear complex 9.
\end{abstract}

TOC Graphic :
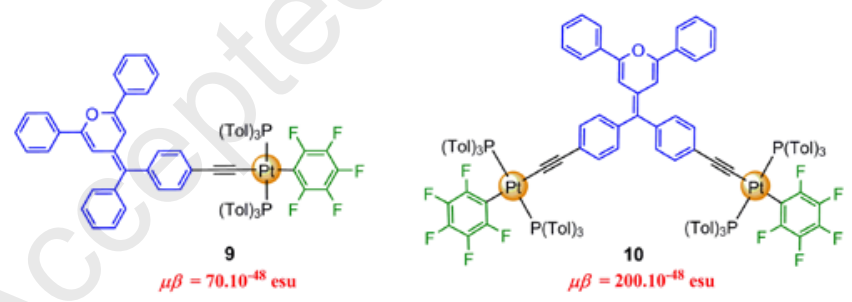


\section{INTRODUCTION}

Considerable research efforts have been recently made to develop organic and organometallic molecular systems exhibiting interesting nonlinear optical (NLO) properties, as they offer potential applications in many fields, including photonics, ${ }^{1}$ photodynamic therapy, ${ }^{2}$ optical limiting devices, ${ }^{3}$ optical data storage ${ }^{4}$ and optoelectronics. ${ }^{5}$ Among these systems, transition metal complexes are particularly attractive. Unlike pure organic chromophores, they display low-energy, high-intensity metal-ligand charge transfer transitions that make these systems quite flexible. For example, their NLO properties can be modified and easily tuned ${ }^{6}$ by changing the nature and/or the oxidation state of the metal center or by varying the type of ligands coordinated to the metal.

Among the above-mentioned organometallic systems, platinum acetylide complexes have been the least investigated, especially compared to their ruthenium counterparts. However, these platinum complexes displayed luminescence and energy photoconversion properties that could make them very attractive candidates in applications such as opto-electronics, photonics and solar cells. ${ }^{7}$ A variety of functional materials ${ }^{8}$ have resulted from the supramolecular selfassemblies $^{9}$ of platinum acetylide complex building blocks. These complexes have also been used as dyes for applications ranging from production of photoinduced energy and hydrogen to electron transfer systems. ${ }^{10}$ Recently, Tian et al. reported on several platinum acetylide complexes exhibiting significant photoconversion efficiencies. ${ }^{11}$ In addition, in these complexes, large NLO responses can be anticipated due to the conjugated character and the linear structure of the alkynyl unit. ${ }^{12}$

Over the past few years, we have developed an interest in synthesizing and studying the properties of asymmetrical push-pull dialkynyl platinum-based complexes exhibiting a D- $\pi-$ $\mathrm{Pt}-\pi-\mathrm{A}$ arrangement, with pyranylidene ligands used as pro-aromatic donor groups (D), ${ }^{13}$ and various $\pi$-linkers coupling on each side the platinum diacetylide unit to the electron-donating (D) and the electron-accepting (A) groups. In our investigations, cyanoacetic groups and diazinyl fragments were used as electron-withdrawing groups (A), and the obtained complexes tested in Dye-Sensitized Solar Cell (DSSC) and NLO devices, respectively. In the first series of complexes containing cyanoacetic groups, all investigated complexes exhibited good photoconversion efficiency (PCE) (up to 4.7\%) depending on the lengths and types of 
the $\pi$-linkers. ${ }^{14}$ The second-order NLO characterization of some complexes resulted in positive $\mu \beta$ values determined by Electric-Field-Induced Second Harmonic (EFISH). These $\mu \beta$ values dramatically increased (up to $3600.10^{-48}$ esu) upon methylation of the pyrimidinyl groups. $^{15}$

These promising results led us to pursue the studies of these platinum complexes. In particular, we became interested in replacing the diazine fragments, by another electronwithdrawing group: pentafluorophenyl $\left(\mathrm{C}_{6} \mathrm{~F}_{5}\right)$. Fluorine, usually in the form of pentafluorophenyl group, has been widely incorporated into organic molecular NLO systems ${ }^{16}$ and organic systems used as dyes in DSSC. ${ }^{17}$ The $\pi-\pi$ stacking ability of the aromatic ring combined with the enhanced electron-withdrawing property of $\mathrm{C}_{6} \mathrm{~F}_{5}$ have made this group an attractive candidate as inductive electron-withdrawing moiety, as both of these characteristics allow to increase the optical transparency and to decrease the optical loss in these compounds. ${ }^{18}$ In addition, push-pull structures bearing a pentafluorophenyl group exhibit low molecular dipole moments. This property allows polymers doped with push-pull systems containing pentafluorophenyl groups to show poling with high temporal stability. ${ }^{16}$

Pentafluorophenyl ligands have also been used in mono- and diplatinum complexes. ${ }^{19}$ For instance, Gladysz and co-workers have synthesized a wide range of symmetrical and asymmetrical pentafluorophenyl-substituted di- and tetraplatinum polyynediyl complexes comprising extended $s p$-hybridized chains. ${ }^{20}$ Several, more intricate structures based on these diplatinum polyynediyl complexes were also reported, where double helices of $s p^{3}$-hybridized carbon chains enveloped $s p$-hybridized carbon chains, ${ }^{21}$ and rotaxane-type assemblies were formed through shielding the $s p$-hybridized chains with a macrocycle. ${ }^{22}$ These platinumalkynyl complexes display long-range electronic charge transfer and represent excellent systems for investigating charge delocalization mechanisms over extended distances. This characteristic led to their use as simple electronic components. ${ }^{23}$

We present herein the synthesis of several push-pull dialkynyl mono- and diplatinum-based complexes incorporating pyranylidene ligands as donor groups, and pentafluorophenyl ligand as inductive accepting groups (Chart 1), and the determination of their second-order NonLinear Optical (NLO) properties. 
We are particularly interested in investigating the impact of the inductive electron-accepting pentafluorophenyl ligand that differs from mesomeric electron acceptor groups typically used in most of the known organometallic "push-pull" structures. We also investigated the presence of two metal centers connected by $\pi$-conjugated bridges, and the length of the $s p$ hybridized carbon chains onto the NLO properties of the systems. In addition to the NLO responses, we also characterized the structures of the synthesized complexes and studied their electrochemical and physical properties.

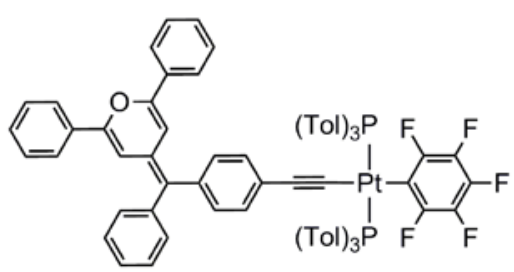

9

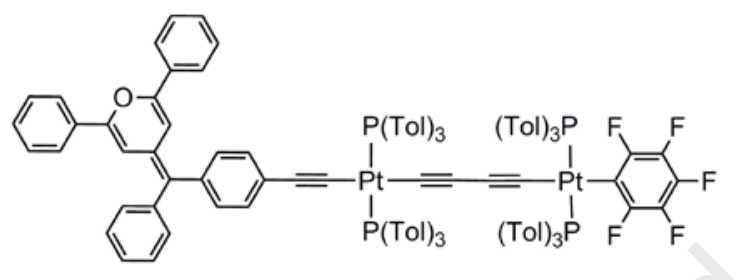

14
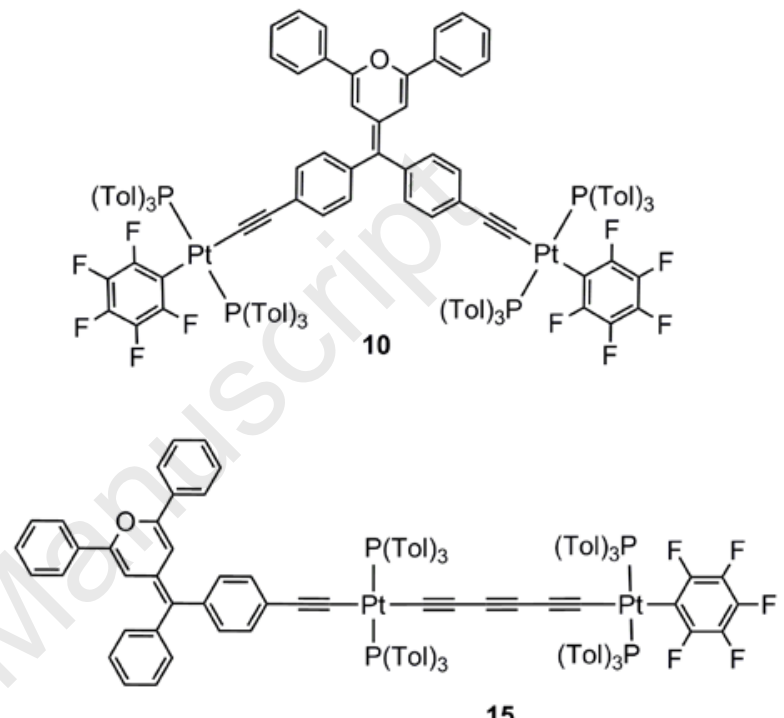

Chart 1: Chemical structures of complexes 9-10 and 14-15.

\section{RESULTS AND DISCUSSION}

Synthesis and Characterization. The synthesis of the complexes required 4-[(4-ethynylphenyl)-phenyl-methylene]-2,6-diphenyl-4H-pyran

6, and 4-(bis(4ethynylphenyl)methylene)-2,6-diphenyl-4H-pyran 7 as starting materials. Compound 6 was prepared following published procedures, ${ }^{14}$ while compound 7 synthesis was a two-step process (Scheme 1). First, a Wittig reaction between tributyl(2,6-diphenyl-4H-pyran-4-yl)phosphonium tetrafluoroborate $\mathbf{1}^{24}$ and bis-(4-(2-trimethylsilylethynyl))benzophenone $\mathbf{3}^{25}$ in presence of $n$-BuLi led to the diphenylpyranylidene unit 5 in good yield. Then, terminal alkyne $\mathbf{7}$ is obtained through the quantitative desilylation of compound $\mathbf{5}$ in basic medium. 


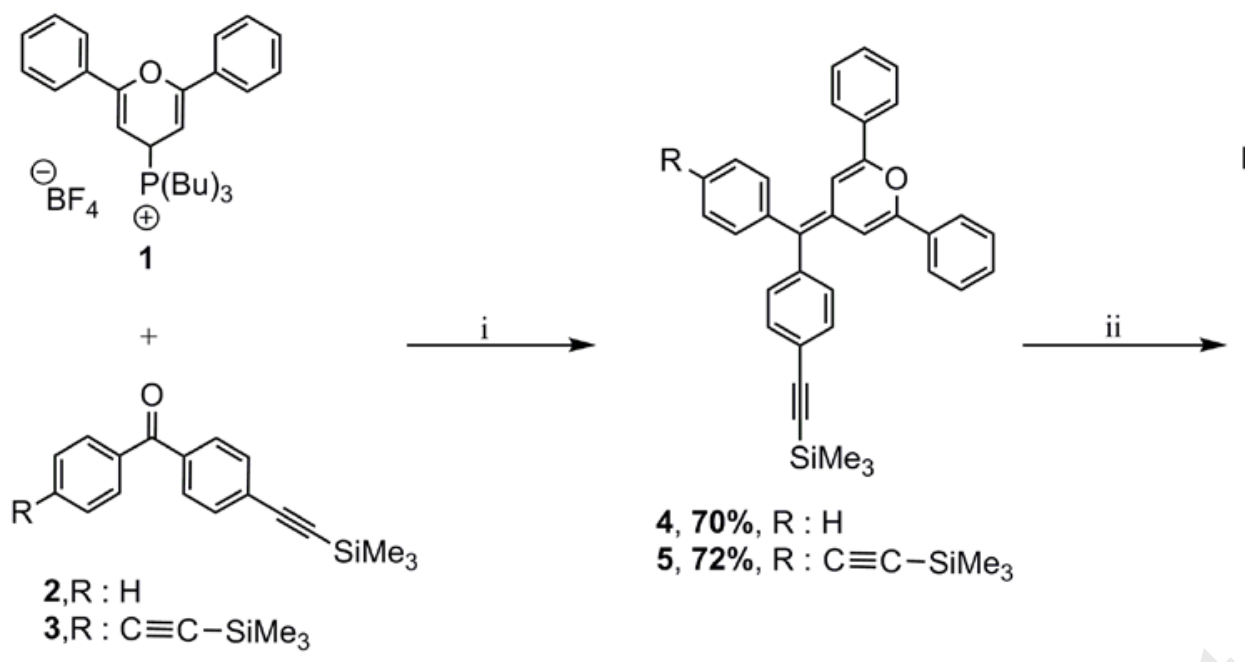

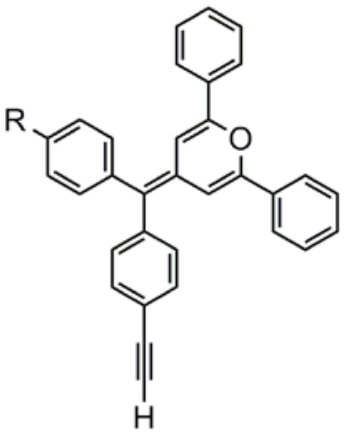

$6,92 \%, \mathrm{R}: \mathrm{H}$

7, $94 \%, \mathrm{R}: \mathrm{C} \equiv \mathrm{C}-\mathrm{H}$

${ }^{a}$ Conditions: (i) n-BuLi, THF, $-78^{\circ} \mathrm{C}$ to rt, 3h; (ii) $\mathrm{K}_{2} \mathrm{CO}_{3}, \mathrm{MeOH} / \mathrm{CH}_{2} \mathrm{Cl}_{2} 1: 2$, rt, $12 \mathrm{~h}$.

The precursor 8 (trans- $\left.\left[\left(\mathrm{C}_{6} \mathrm{~F}_{5}\right)\left(\mathrm{Tol}_{3} \mathrm{P}\right)_{2} \mathrm{PtCl}\right]\right),{ }^{19 \mathrm{~d}}$ and the complexes $\mathbf{1 1}^{14}$ (4-[(4-ethynylphenyl)-phenyl-methylene]-2,6-diphenyl-4H-pyran-susbtituted chloride), 12 (trans$\left.\left[\left(\mathrm{C}_{6} \mathrm{~F}_{5}\right)\left(\mathrm{Tol}_{3} \mathrm{P}\right)_{2} \mathrm{Pt}(\mathrm{C} \equiv \mathrm{C})_{2} \mathrm{H}\right]\right)$ and $\mathbf{1 3}$ (trans- $\left[\left(\mathrm{C}_{6} \mathrm{~F}_{5}\right)\left(\mathrm{Tol}_{3} \mathrm{P}\right)_{2} \mathrm{Pt}(\mathrm{C} \equiv \mathrm{C})_{3} \mathrm{SiEt}_{3}\right]$ ) were synthesized according to previously reported procedures. ${ }^{20 \mathrm{~d}}$ The synthetic approach to the asymmetrical platinum complex 9 and the diplatinum complexes 10, 14, and 15 (Schemes 2 and 3), was performed using widely reported substitution of platinum chloride complexes by terminal acetylenes. ${ }^{14,15,19,20,21}$ All complexes were prepared under similar conditions by conventional cross-coupling reaction catalyzed by copper(I) iodide, in diethylamine and THF. The reactions were conducted overnight under ambient temperature and led to the complexes $\mathbf{9}$, 10, 14, and 15 in 70 to $82 \%$ yields. As shown in Scheme 3, trans-[( $\left.\left.\mathrm{C}_{6} \mathrm{~F}_{5}\right)\left(\mathrm{Tol}_{3} \mathrm{P}\right)_{2} \mathrm{Pt}(\mathrm{C} \equiv \mathrm{C})_{3} \mathrm{H}\right]$ was generated in situ from trans- $\left[\left(\mathrm{C}_{6} \mathrm{~F}_{5}\right)\left(\mathrm{Tol}_{3} \mathrm{P}\right)_{2} \mathrm{Pt}(\mathrm{C} \equiv \mathrm{C})_{3} \mathrm{SiEt}_{3}\right] \mathbf{1 3}$ and $n \mathrm{Bu}_{4} \mathrm{~N}^{+} \mathrm{F}$. The progress of the reactions was monitored by ${ }^{31} \mathrm{P}$ NMR, revealing the concomitant consumption of the starting material and the formation of the products $\mathbf{9}, \mathbf{1 0}, \mathbf{1 4}$, and $\mathbf{1 5}$. The new complexes 9, 10, 14, and 15 were characterized by IR, UV/Vis, NMR $\left({ }^{1} \mathrm{H},{ }^{31} \mathrm{P},{ }^{19} \mathrm{~F}\right.$ and $\left.{ }^{13} \mathrm{C}\right)$ and high-resolution mass spectroscopies. These characterizations match up the suggested structures. 
The signature $v_{\mathrm{C} \equiv \mathrm{C}}$ band of the metal-bonded alkynyl group, in the $2228-2103 \mathrm{~cm}^{-1}$ range, is observed on the IR spectra of the complexes 9, 10, 14, and 15. Characteristic signals of the vinylic $H$ resonance of the methylenepyran (singlet at $\delta=6.70 \mathrm{ppm}$ ), of the disubstituted phenyl rings (two doublet signals at $\delta=7.50$ and $7.25 \mathrm{ppm} ;{ }^{3} J_{\mathrm{HH}}=7.9$ and $8.1 \mathrm{~Hz}$ ) and of the alkyne protons (singlet at $\delta=3.15 \mathrm{ppm}$ ) were observed on the ${ }^{1} \mathrm{H}$ NMR spectrum of the symmetrical ligand 7. In complex 10, the inductive effect of the platinum coordination resulted in an upfield shift of the hydrogen atoms of the disubstituted phenyl rings $(\delta=6.65$ and $6.19 \mathrm{ppm})$ and of the vinylic protons $(\delta=6.49 \mathrm{ppm})$ of the methylenepyran. The complexes 9, 14, and 15 display similar shifts. The ${ }^{1} \mathrm{H}$ and ${ }^{13} \mathrm{C}$ NMR spectra of the complexes 9, 10, 14, and 15 show the expected peaks for the tri(p-tolyl)phosphines, the pyranylidene ligand and the $\pi$-conjugated linker. The ${ }^{31} \mathrm{P}$ NMR spectra of the monoplatinum complex $\mathbf{9}$ and the symmetrically substituted diplatinum $\mathbf{1 0}$ display sharp singlets, indicating that the phosphine ligands coordinated to the platinum adopted trans geometries (for example $\delta=$ $17.61 \mathrm{ppm},{ }^{1} J_{\mathrm{PtP}}=2691 \mathrm{~Hz}$, for 9). Due to the asymmetrical substitutions of the platinum moieties on butadiynediyl 14 and hexatriynediyl 15 complexes, the ${ }^{31} \mathrm{P}$ NMR spectra show two phosphorus signals (for example $\delta=16.31 \mathrm{ppm},{ }^{1} J_{\mathrm{PtP}}=2708 \mathrm{~Hz}, 14.69 \mathrm{ppm},{ }^{1} J_{\mathrm{PtP}}=2627$ $\mathrm{Hz}$, for 14). Finally, ${ }^{19} \mathrm{~F}$ NMR spectra of the complexes display three multiplet signals that can be attributed to the three different fluorine atoms on the pentafluorophenyl groups.

\section{Scheme 2: Synthesis of mono- and diplatinum complexes 9-10}
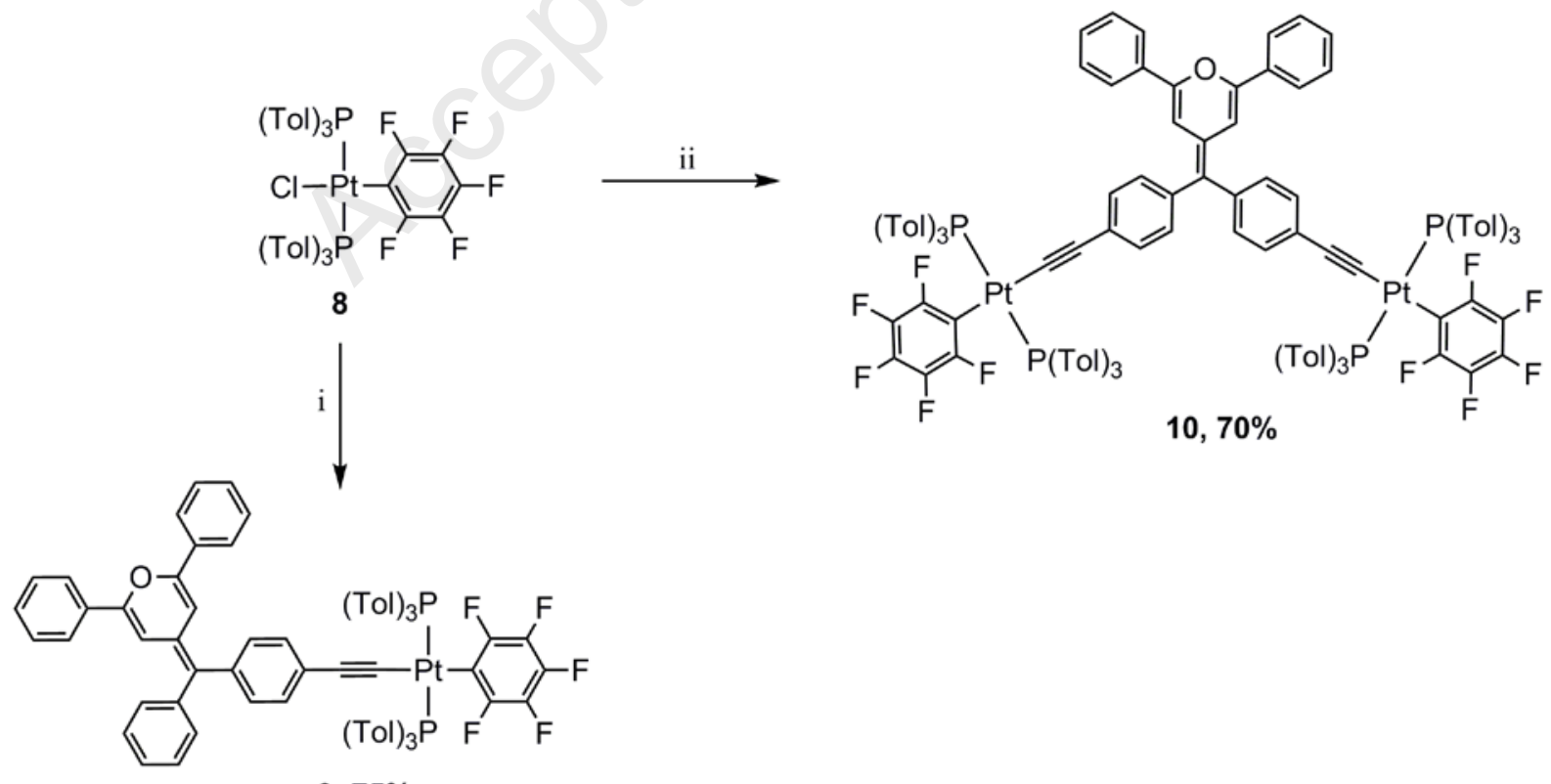

$9,75 \%$

${ }^{a}$ Conditions: (i) 1.2 equiv of 4-[(4-ethynyl-phenyl)-phenyl-methylene]-2,6-diphenyl-4H-pyran 6, CuI, THF/Et ${ }_{2} \mathrm{NH}$ 1:2, rt, $12 \mathrm{~h}$; (ii) 0.5 equiv of 4-(bis(4-ethynylphenyl)methylene)-2,6-diphenyl-4H-pyran 7, $\mathrm{CuI}, \mathrm{THF} / \mathrm{Et}_{2} \mathrm{NH} 1: 2$, rt, $12 \mathrm{~h}$. 


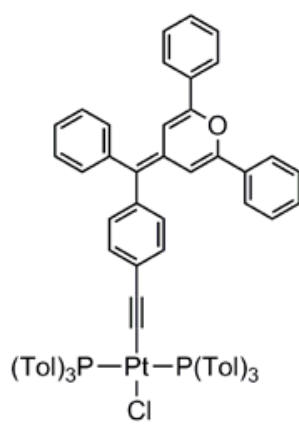

11

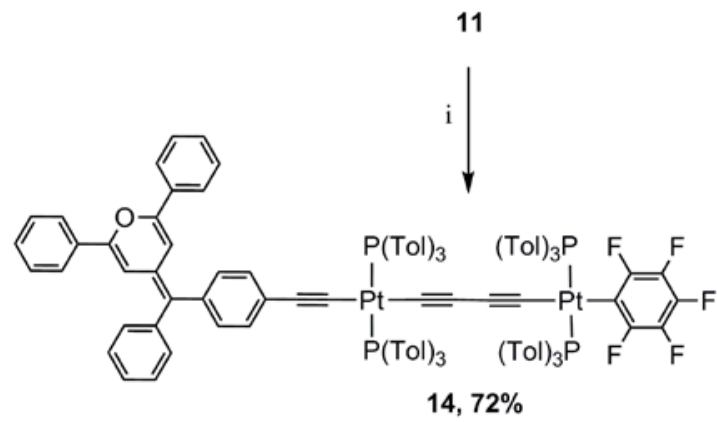

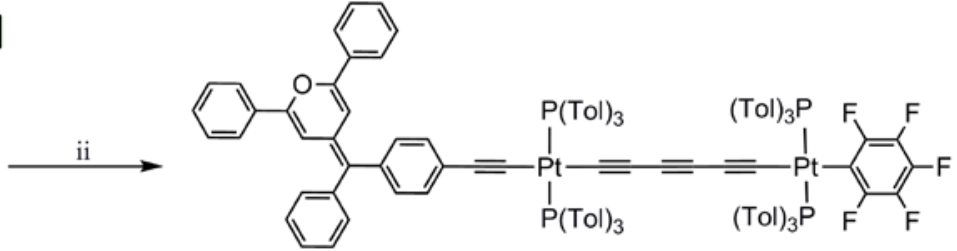

$15,76 \%$

${ }^{a}$ Conditions: (i) 1 equiv of trans- $\left[\left(\mathrm{C}_{6} \mathrm{~F}_{5}\right)\left(\mathrm{Tol}_{3} \mathrm{P}\right)_{2} \mathrm{Pt}(\mathrm{C} \equiv \mathrm{C})_{2} \mathrm{H}\right]$ 12, CuI, THF/Et $\mathrm{NH}_{2} \mathrm{~N}$ :2, rt, 48h; (ii) 1 equiv of trans- $\left[\left(\mathrm{C}_{6} \mathrm{~F}_{5}\right)\left(\mathrm{Tol}_{3} \mathrm{P}\right)_{2} \mathrm{Pt}(\mathrm{C} \equiv \mathrm{C})_{3} \mathrm{SiEt}_{3}\right] \mathrm{13}, n \mathrm{Bu}_{4} \mathrm{~N}^{+} \mathrm{F}$, THF, 30 min and $\mathrm{CuI}_{2} \mathrm{Et}_{2} \mathrm{NH}$, rt, 48h.

Structural Description. For the determination of the crystallographic structures, complexes 9, and $\mathbf{1 4}$ were grown as monocrystals by the slow diffusion of pentane into a concentrated solution of $\mathbf{9}$ in dichloromethane and of $\mathbf{1 4}$ in chloroform. Figures 1 and 2 give the thermal ellipsoid plots obtained from the crystallographic structures. The crystallographic data and structure refinement details are given in Tables S1 and S2 in the Supporting Information (SI). ${ }^{26}$ The monoplatinum complex 9 crystallizes in the monoclinic space group, with a slightly distorted square planar geometry around the four-coordinated platinum atom (Figure 1). The molecular structure confirms the trans configuration of the pentafluorophenyl group, the pyranylidene ligand and the two tri(p-tolyl)-phosphines around the platinum center. Typical bond lengths and angles around the platinum were determined. ${ }^{14}$ The $\mathrm{C} 1-\mathrm{Pt}-\mathrm{C} 2 \equiv \mathrm{C} 3$ group adopt an almost linear structure with $\mathrm{Pt}-\mathrm{C} 2 \equiv \mathrm{C} 3$ and $\mathrm{C} 1-\mathrm{Pt}-\mathrm{C} 2$ angles of $176.3(6)^{\circ}$ and $172.40(3)^{\circ}$, respectively. In contrast, the P1-Pt-P2 angle is slightly more bent at 169.73(6). The Pt-C2 distance of 1.994(6) $\AA$ and the $\mathrm{C} 1 \equiv \mathrm{C} 2$ bond length of 1.213(9) $\AA$ are consistent with those observed for other platinum coordinated to acetylide ligands. ${ }^{27}$ The exocyclic bond C8-C9 of the methylenepyran was found to be 1.357(9) A long, which is slightly lower than the range of the exocyclic $\mathrm{C}-\mathrm{C}$ bond lengths (1.39-1.40 $\AA$ ) generally reported in 
methylenepyran Fischer-type carbine complexes. In these complexes, the electron withdrawing effect of the carbene moiety leads to a ground state structure leaning to the cyanine limit, ${ }^{28}$ while the exocyclic bond C8-C9 measured in complex 9 suggests a weak pyryllium character for this complex structure.

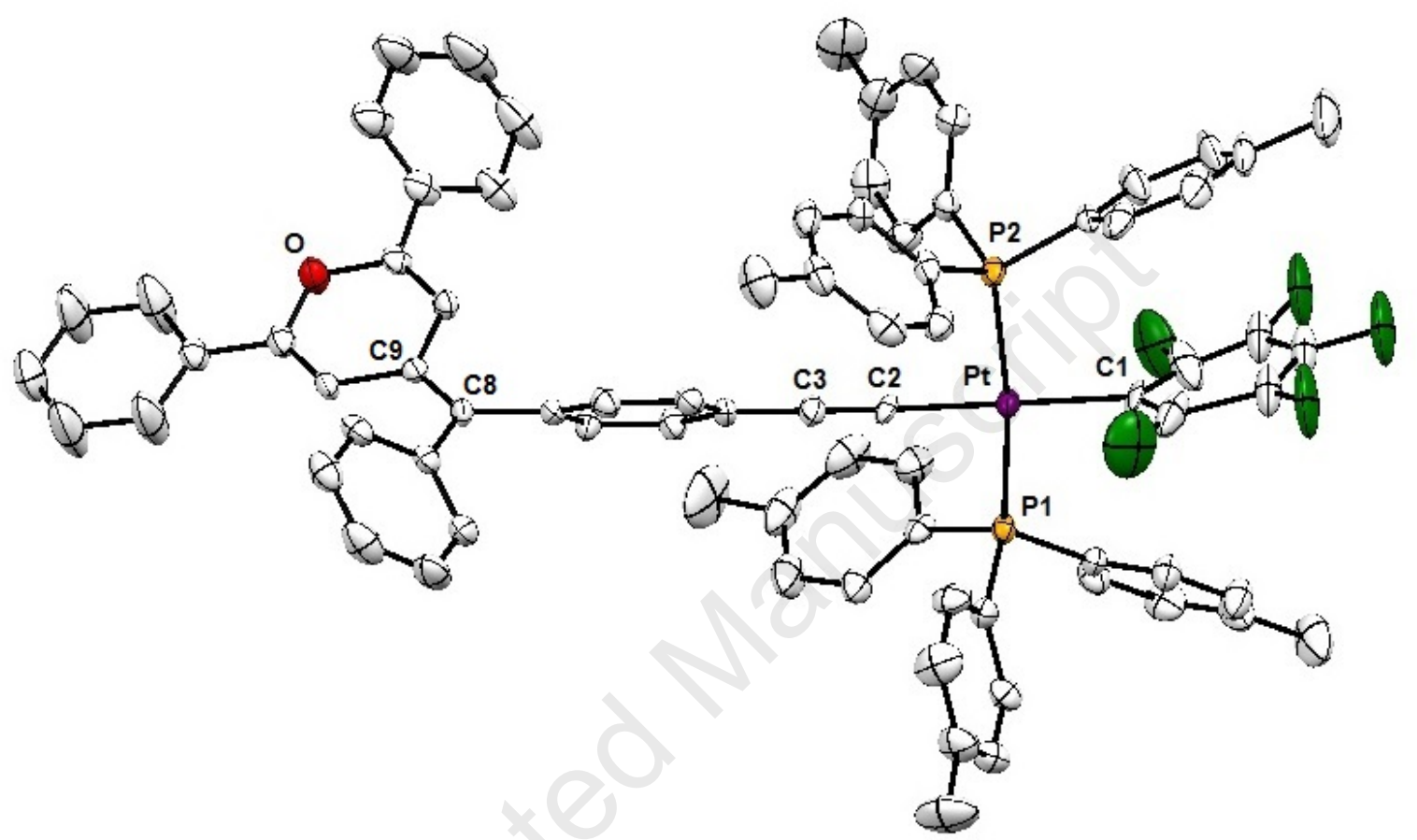

Figure 1. ORTEP drawing of the monoplatinium complex 9 with thermal ellipsoids at $50 \%$ probability level. All hydrogen atoms and solvent molecules are omitted for clarity. Selected bond distances $(\AA)$, and angles (deg): C1-Pt = 2.069(6), Pt-C2 = 1.994(6), Pt-P2 = 2.2952(17), $\mathrm{C} 2-\mathrm{C} 3$ = 1.213(9), C8-C9 = 1,357(9); C1-Pt-C2 = 172.40(3), P1-Pt-P2 = 169.73(6), Pt-C2-C3 = 176.30(6), P2-Pt-C1 = 92.05(17), P2-Pt-C2 = 85.20(2).

Unlike the monoplatinum complex 9, the diplatinum complex 14 crystallizes in the triclinic space group (Figure 2). The bond lengths and angles in the tetraphosphine complex 14 with $\operatorname{Pt}(\mathrm{C} \equiv \mathrm{C})_{2} \mathrm{Pt}$ linkage were typical and similar to those reported for the asymmetrically butadiynediyl-substituted diplatinum analogues (Figure 3). ${ }^{20 \mathrm{~b}}$ The $\mathrm{C} 2 \equiv \mathrm{C} 3, \mathrm{C} 4 \equiv \mathrm{C} 5$ and $\mathrm{C} 6 \equiv \mathrm{C} 7$ bond lengths are within the normal range of 1.210(6), 1.215(6) and 1.202(6) $\AA$, respectively. In addition, the platinum-platinum Pt1 ••Pt2 distance (7.798 $\AA$ ) is slightly below the sum of all the intermediary bond lengths $(7.814 \AA)$. The $\mathrm{Pt} 1-\mathrm{C} 2 \equiv \mathrm{C} 3-\mathrm{C} 4 \equiv \mathrm{C} 5-\mathrm{Pt} 2$ chain is quasilinear, 
with angles in the ranges of 173.7(4)-179.60(5) ${ }^{\circ}$. The diplatinum complex 14 presents a significant "twist" associated with the square planar end-groups with an angle measured at 8. $7^{\circ}$. In this approach, the angle between the planes in the crystal structure were determined by using the P-Pt-P bonds on one segment, and the platinum from the other ([P1Pt1P2]-Pt2 vs. [P3Pt2P4]-Pt1).

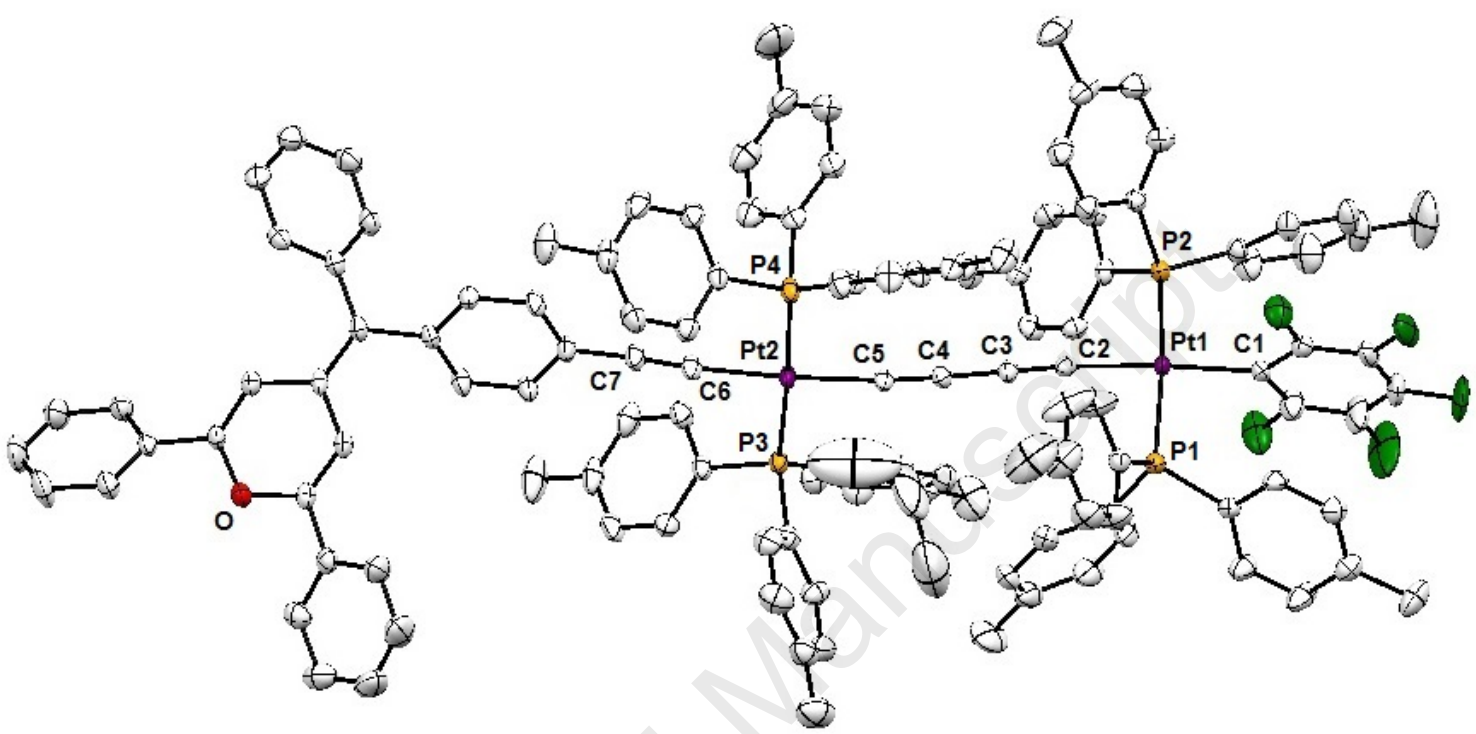

Figure 2. ORTEP drawing of the diplatinium complex 14 with thermal ellipsoids at $50 \%$ probability level. All hydrogen atoms and solvent molecules are omitted for clarity. Selected bond distances $(\AA \AA)$, and angles (deg): C1-Pt1 = 2.058(4), Pt1-C2 = 2.007(4), Pt1-P2 = 2.3037(11), $\mathrm{C} 2-\mathrm{C} 3=1.2010(6), \mathrm{C} 3-\mathrm{C} 4=1.383(6), \mathrm{C} 4-\mathrm{C} 5=1.215(6), \mathrm{C} 5-\mathrm{Pt} 2=1.999(4), \mathrm{Pt} 2-\mathrm{P} 4=2.3054(11)$, Pt2-C6 = 1.996(4) C6-C7 = 1.202(6); C1-Pt1-C2 = 175.87(17), P1-Pt1-P2 = 173.98(4), Pt1-C2-C3 = 175.30(4), P1-Pt1-C1 = 92.12(12), P1-Pt1-C2 = 83.76(12), C2-C3-C4 = 179.30(5), C3-C4-C5 = 177.00(5), C5-Pt2-C6 = 176.14(19), P3-Pt2-P4 = 176.62(4), Pt2-C5-C4 = 173.70(4), Pt2-C6-C7 = 175.60(4), P4-Pt2-C5 = 90.42(12), P4-Pt2-C6 = 87.89(13). 
Photophysical Properties. Complexes 9-10 and 14-15 UV-Vis absorption spectra, recorded in diluted dichloromethane are shown on Figure 3, and the corresponding spectroscopic data are collected in Table 1. Complexes $\mathbf{9}$ and $\mathbf{1 0}$ both exhibit a single major prominent band at $391 \mathrm{~nm}$ on their UV-visible spectra, while complexes 14 and $\mathbf{1 5}$ display multiples bands in the 330-410 nm range that can therefore be viewed as signature of the multi-ethynyl bridge. Indeed, as observed in the UV-visible spectra of a series of polyynes platinum complexes of increasing conjugated lengths, ${ }^{29}$ the complexes 14-15 spectra display more absorption bands of increasing intensities. In most push-pull complexes, the lower-energy absorption bands can be attributed to an intramolecular charge-transfer (ICT) transition between the electron donor and the electron acceptor fragments. ${ }^{15}$ In complexes 9-10 and 14-15 the lower-energy absorption bands $\lambda_{\max }$ in the 330-410 nm range are observed and correlate with intra-ligand charge transfer (ICT) transitions $\left(\pi-\pi^{*}\right)$ centered on the pyranylidene moieties (see TD-DFT calculations for additional information). Extinction coefficient of the complex $\mathbf{1 5}$ is significantly larger than that of the complex 14 which displays an extinction coefficient of 3.0 $\times 10^{4} \mathrm{M}^{-1} \mathrm{~cm}^{-1}$ at $404 \mathrm{~nm}$, while complex 15 extinction coefficient is $5.2 \times 10^{4} \mathrm{M}^{-1} \mathrm{~cm}^{-1}$ at $391 \mathrm{~nm}$. Complex 15 displays a maximum absorption more intense than that of complex 14. This can be explained by the partial contribution on the ethynyl linkers in the electron delocalization toward the pyranylidene moieties.

Table 1. Absorption property of the complexes 9-10 and 14-15 recorded in dichloromethane solution $\left(2 \times 10^{-5} \mathrm{M}\right)$ at room temperature.

\begin{tabular}{cc}
\hline Complex & $\begin{array}{c}\lambda_{\text {max }}^{\text {abs }} / \mathbf{n m} \\
\left(\boldsymbol{\varepsilon} \times \mathbf{1 0}^{\mathbf{4}} \mathbf{M}^{-\mathbf{1}} \cdot \mathbf{c m}^{-\mathbf{1}}\right)\end{array}$ \\
\hline $\mathbf{9}$ & $391(4,1)$ \\
$\mathbf{1 0}$ & $391(4,3)$ \\
$\mathbf{1 4}$ & $347(2,9), 404(3,0)$ \\
$\mathbf{1 5}$ & $339(4,3), 362(4,4), 391(5,2)$ \\
\hline
\end{tabular}




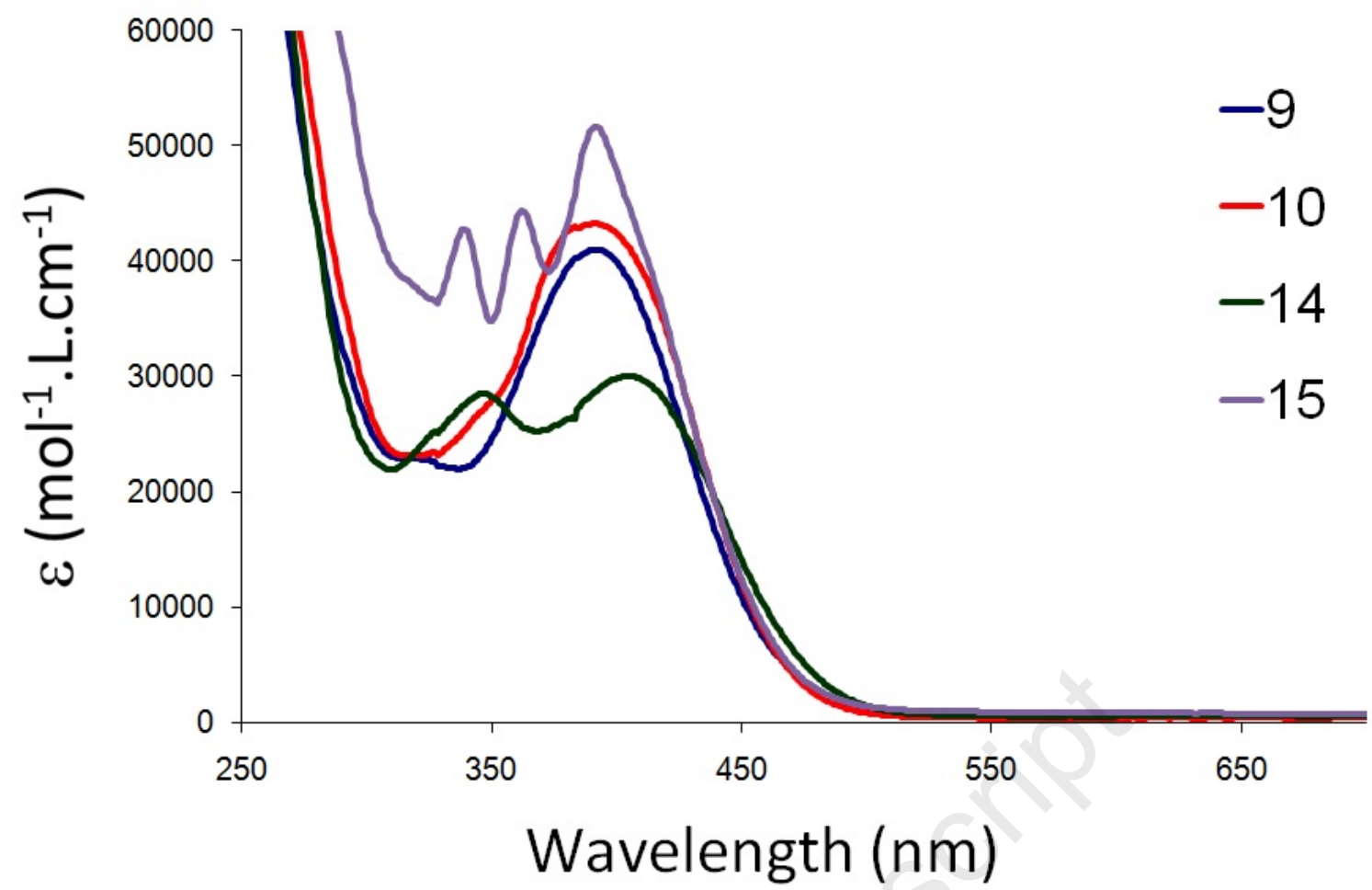

Figure 3. UV-Vis absorption spectra of complexes 9-10 and 14-15 in dichloromethane solution (2 $\left.\times 10^{-5} \mathrm{M}\right)$ at room temperature.

Electrochemical Properties. Cyclic voltammetry (CV) studies of complexes 9-10 and 14-15 were recorded in $\mathrm{CH}_{2} \mathrm{Cl}_{2} / \mathrm{NBu}_{4} \mathrm{PF}_{6} 0.1 \mathrm{M}$ by using a platinum working electrode. Table 2 lists the electrochemical data. The mono-Pt complex 9 displays two reversible systems at $E^{0^{\prime}}(1)=$ $0.14 \mathrm{~V}$ and $E^{0^{\prime}}(2)=0.41 \mathrm{~V}$ vs. Fc (Figure 4). Its redox behavior is similar to that obtained for its chloro-pyranylidene analogous complex $11(0.14 \mathrm{~V}$ and $0.37 \mathrm{~V}$, see Table 2). This indicates that the pentafluorophenyl moiety does not substantially participate in the delocalization of the charge upon oxidation. Such result is consistent with the theoretical calculations (vide infra, Figure 5). Coulometric analysis of the exhaustive electrolysis of the solution at $0.60 \mathrm{~V}$ indicates a global uptake of two electrons, hence suggesting that the processes (1) and (2) are monoelectronic. The insertion of one diacetylene (complex 14) or one trisacetylene (complex 15) Pt unit between the pentafluorophenyl group and the first Pt center induces a slight decrease of the formal potential values for both processes (1) and (2) compared to those of complex 9 (Figure 4, and Table 2). Hence, the second Pt acetylene unit stabilizes the pyrylium radical cation likely through charge delocalization. In addition, the CV studies display a third reversible redox reaction at higher potential values for these two complexes $\left(E^{0^{\prime}}(3)=0.64 \mathrm{~V}\right.$ and $0.73 \mathrm{~V}$ for 14 and 15, respectively). According to previous studies performed on pentafluorophenyl Pt complexes, the system at $E^{0^{\prime}}(3)$ can be ascribed to 
the oxidation of the bis-platinum core on both compounds. ${ }^{20 b, 20 \mathrm{~d}}$ For instance, the trans,trans$\left(\mathrm{C}_{6} \mathrm{~F}_{5}\right)\left(\mathrm{PTol}_{3}\right)_{2} \mathrm{Pt}(\mathrm{C} \equiv \mathrm{C})_{3} \mathrm{Pt}\left(\mathrm{PTol}_{3}\right)_{2}(\mathrm{Tol})$ complex which is an analogue of $\mathbf{1 5}$ displays an oxidation peak at $0.58 \mathrm{~V}$ vs. Fc in dichloromethane. ${ }^{20 \mathrm{~b}}$ Noteworthy, the complex $\mathbf{1 0}$ exhibits rather low potential values upon oxidation $\left(E^{0^{\prime}}(1)=0.08 \mathrm{~V}\right.$ and $E^{0^{\prime}}(2)=0.31 \mathrm{~V}$, see Table 2, Figure S22, SI) by comparison to complex 9. Its redox behavior can be correlated to its specific architecture, since the two pentafluorophenyl Pt units are symmetrically positioned on each side of the pyranylidene. The decrease of the potential (vs complex 9) can be assigned to the stronger stabilization of the electrochemically generated pyrylium radical cation $\mathbf{1 0}^{+\bullet}$ and dication $\mathbf{1 0}^{\mathbf{2 +}}$. This effect occurs because the charge is likely delocalized over the two phenylacetylene units, instead of one for $\mathbf{9}, \mathbf{1 4}$ and $\mathbf{1 5}$, in agreement with the symmetry of the molecule. This proposition is consistent with the difference of localization of the spin density calculated for the SOMOs of complexes $\mathbf{9}^{+\bullet}$ and $\mathbf{1 0}^{+\bullet}$ (Figure S23, SI).

Table 2. Electrochemical data for complexes $9,10,11,14$, and $15(0.5 \mathrm{mM})$ at a Pt working electrode in $\mathrm{CH}_{2} \mathrm{Cl}_{2} / \mathrm{NBu}_{4} \mathrm{PF}_{6} 0.1 \mathrm{M}\left(E / \mathrm{V}\right.$ vs. $\left.\mathrm{Fc}^{+} / \mathrm{Fc}, v=0.1 \mathrm{~V} \mathrm{~s}^{-1}\right)$.

\begin{tabular}{cllllll}
\hline Complex & $\boldsymbol{E}_{\mathbf{p a}}(\mathbf{1})$ & $\boldsymbol{E}^{\mathbf{0}^{\prime}} \mathbf{( 1 )}$ & $\boldsymbol{E}_{\mathbf{p a}}(\mathbf{2})$ & $\boldsymbol{E}^{\mathbf{0}^{\mathbf{\prime}}} \mathbf{( 2 )}$ & $\boldsymbol{E}_{\mathbf{p a}} \mathbf{( 3 )}$ & $\boldsymbol{E}^{\mathbf{0}} \mathbf{( 3 )}$ \\
\hline $\mathbf{9}$ & 0.21 & 0.14 & 0.48 & 0.41 & & \\
$\mathbf{1 0}$ & 0.12 & 0.08 & 0.37 & 0.31 & & \\
$\mathbf{1 1}$ & 0.18 & 0.14 & 0.41 & 0.37 & & \\
$\mathbf{1 4}$ & 0.15 & 0.12 & 0.36 & 0.32 & 0.68 & 0.64 \\
$\mathbf{1 5}$ & 0.17 & 0.13 & 0.40 & 0.36 & 0.77 & 0.73 \\
\hline
\end{tabular}
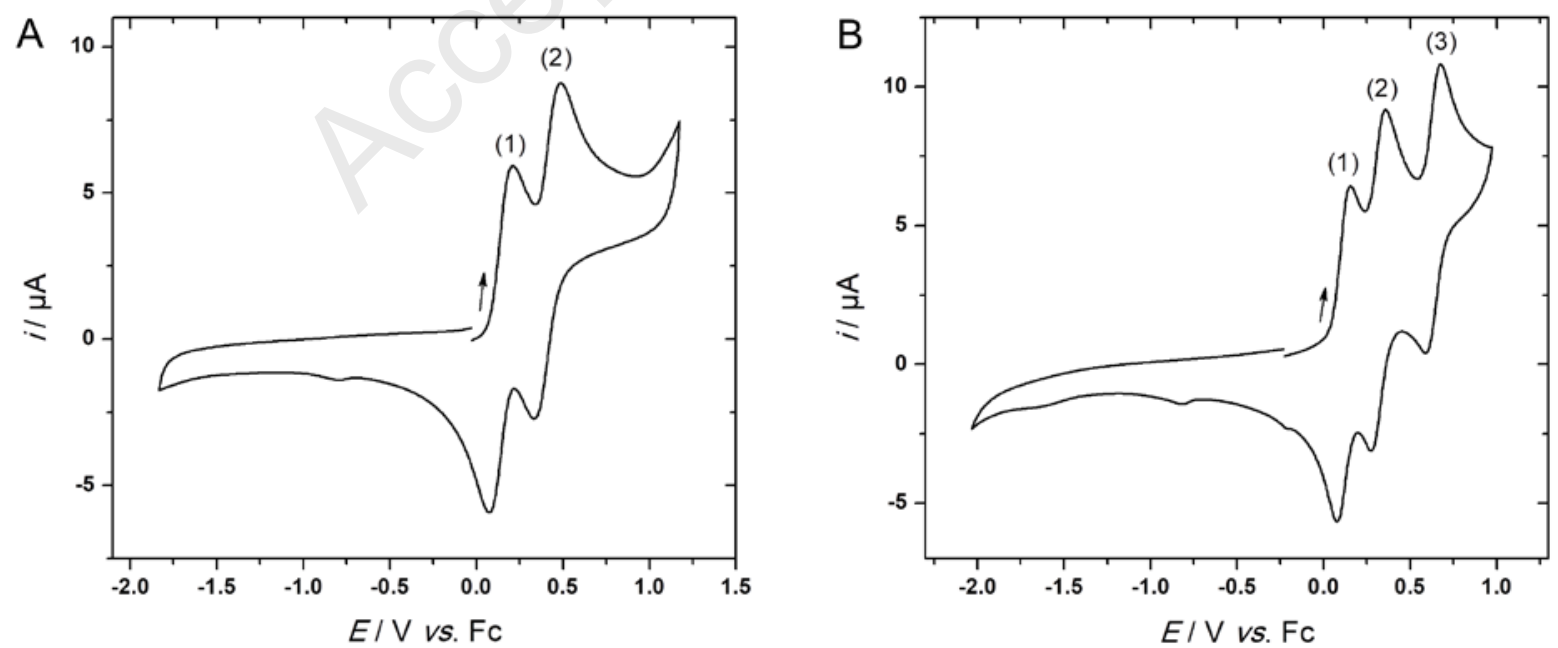

Figure 4. Cyclic voltammograms at a Pt working electrode of complexes 9 (panel A) and 14 (panel B) in $\mathrm{CH}_{2} \mathrm{Cl}_{2} / \mathrm{NBu}_{4} \mathrm{PF}_{6} 0.1 \mathrm{M}\left(E / \mathrm{V}\right.$ vs. Fc $\left.{ }^{+} / \mathrm{Fc}, v=0.1 \mathrm{~V} \mathrm{~s}^{-1}, C=0.5 \mathrm{mM}\right)$. The arrows indicate the scanning direction. The numbers (1), (2) and (3) refer to the redox systems, see text for details. 
Second-Order NLO Measurements. Complexes 9, 10, 14, and 15 second-order NLO responses were determined by the EFISH method in chloroform with a non-resonant incident wavelength of $1907 \mathrm{~nm}$, following experimental conditions described in the literature. ${ }^{30}$ It is worth mentioning that there is not overlap between the second harmonic at a wavelength of $953 \mathrm{~nm}$ and any of the absorption bands of the chromophores. As previously reported, the EFISH technique provides information about $\mu \beta(2 \omega)$, the scalar product of the vector component of the first hyperpolarizability tensor $(\beta)$ and the dipole moment vector, $\mu^{31}$ of the chromophores, as shown on Eq. 1. For the studied Complexes 9, 10, 14, and 15, we assumed that the third-order term $\left(\gamma_{0}(-2 \omega, \omega, \omega, 0)\right)$ in this equation was negligible.

$$
\gamma_{\text {EFISH }}=\mu \beta / 5 \mathrm{kT}+\gamma_{0}(-2 \omega, \omega, \omega, 0) \quad \text { Eq. } 1
$$

The EFISH measurements are gathered in Table 3. All complexes exhibited positive $\mu \beta$ values, indicating that the excited states of the chromophores are more polarized than their ground states. In addition, these results confirm that chromophores ground and excited states are polarized in the same direction. For all four complexes, $\mu \beta$ values are rather low and the margin of error is probably higher than the $\pm 10 \%$ value generally reported for EFISH measurements. Complexes 9, 14, and 15 exhibited similar NLO response. This seems to indicate that an increase in the length of the polyyne linker or the addition of a second platinum center have essentially no major impact on the NLO response, which is qualitatively consistent with the theoretical calculations (vide infra, Figure 5). On the other hand, the Vshaped complex 10 displays a NLO responses ( $\mu \beta$ value) more than twice higher than that of the linear complex 9, in part due by the larger dipole moment induced by this specific configuration. These trends are consistent with results previously presented. ${ }^{32}$

Table 3. Measured $\mu \beta$ values, theoretically determined dipole moment $\mu$ and deduced secondhyperpolarizability $\beta$ for complexes $9,10,14$, and 15 .

\begin{tabular}{ccccc}
\hline & $\mathbf{9}$ & $\mathbf{1 0}$ & $\mathbf{1 4}$ & $\mathbf{1 5}$ \\
\hline $\boldsymbol{\mu} \boldsymbol{\beta}\left[\mathbf{1 0}^{-\mathbf{4 8}} \mathbf{e s u}\right]^{\mathrm{a}}$ & 70 & 200 & 110 & 60 \\
$\boldsymbol{\mu}[\mathbf{D}]$ & 3.5 & 6.0 & 5.1 & 5.3 \\
$\boldsymbol{\beta}\left[\mathbf{1 0}^{-30} \mathbf{e s u}\right]$ & 20 & 33 & 22 & 11.3 \\
\hline
\end{tabular}

${ }^{\text {a }} \mu \beta(2 \omega)$ at $1907 \mathrm{~nm}$ in $\mathrm{CHCl}_{3}$. Molecular concentrations used for the measurements were in the range of $10^{-2}$ to $10^{-3} \mathrm{M}$. 
The low $\mu \beta_{\text {EFISH }}$ values observed in the present work are consistent with, yet lower than, those obtained in previous studies of similar platinum complexes. For example, P. Nguyen et al. described the synthesis and the NLO properties of several asymmetrical platinum bis(phenylacetylide) complexes substituted with various donor-acceptor groups. ${ }^{33}$ Their Pt bis(acetylide) complex containing a $p$-methoxyphenyl fragment as donor group and a $p$ nitrophenyl fragment as acceptor group exhibits a moderate $\mu \beta_{\text {EFISH }}$ value of $310 \times 10^{-48}$ esu (operating at $1064 \mathrm{~nm}$ ). We recently reported the second order NLO responses of a series of $\mathrm{D}-\pi$-Pt- $\pi$-A platinum complexes made of a platinum bis(acetylide) segment separated from electron donor pyranylidene and electron acceptor pyirimidine groups by $\pi$-conjugated linkers. ${ }^{15}$ These neutral complexes also showed relatively low $\mu \beta$ values between 170 to $390 \times$ $10^{-48}$ to esu (operating at $1907 \mathrm{~nm}$ ). However, unlike these complexes, the complexes presented in this work contained an inductive accepting group with the pentafluorophenyl ligand that would lead to lower $\mu \beta$ values.

Theoretical Calculations. Theoretical calculations (see experimental section for details) were used to confirm the experimental data and obtain a better understanding of the complex properties. For all molecules, TD-DFT shows that the lowest electronic excited state presents a large oscillator strength and is located at ca. $400 \mathrm{~nm}$, which fits experiment. More specifically, the theoretical analyses was able to determine transitions at $396 \mathrm{~nm}(f=1.31), 405$ $\mathrm{nm}(f=1.50), 399 \mathrm{~nm}(f=1.58)$ and $399 \mathrm{~nm}(f=1.62)$ for $\mathbf{9}, \mathbf{1 0}, \mathbf{1 4}$, and $\mathbf{1 5}$, respectively. In all cases, these transitions can be mainly ascribed to HOMO to LUMO electronic promotions. These orbitals are displayed in Figure 5. For each complex, both orbitals are largely localized on the pyranylidene moieties. Remarkably, the HOMO displays a partial contribution on the ethynyl linkers, but nothing on the two external phenyl rings of the pyranylidene, unlike the LUMO, which shows significant contribution on these two phenyls. There is therefore a significant charge-transfer in these systems, even though the pentafluorophenyl moieties play no role in it. As often in very large compounds, the ICT does not take place from one end of the molecule to the other, ${ }^{34}$ but, in contrast, the $\pi$-conjugated bridge plays the role of donor. The shapes of the LUMO, that are similar in $\mathbf{9 , 1 0}$, and $\mathbf{1 5}$ are also consistent with the fact that these compounds show similar NLO response. The DFT computed $\beta(-2 \omega ; \omega, \omega)$ at $1907 \mathrm{~nm}$ are 23, 39, 34 and $29 \times 10^{-30}$ esu for $\mathbf{9}, \mathbf{1 0}, \mathbf{1 4}$, and 15, respectively. These values are obviously of the same order of magnitude as the one measured, with the maximal response 
obtained for 10, due to its arrangement allowing for a "double" ICT transition as shown on Figure 5.

9
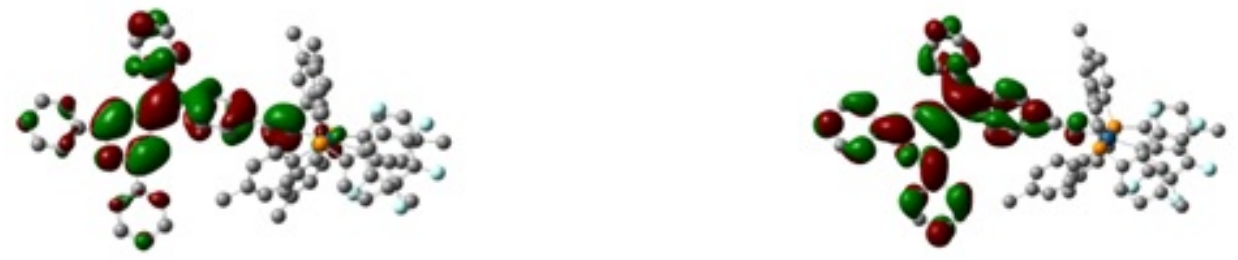

10
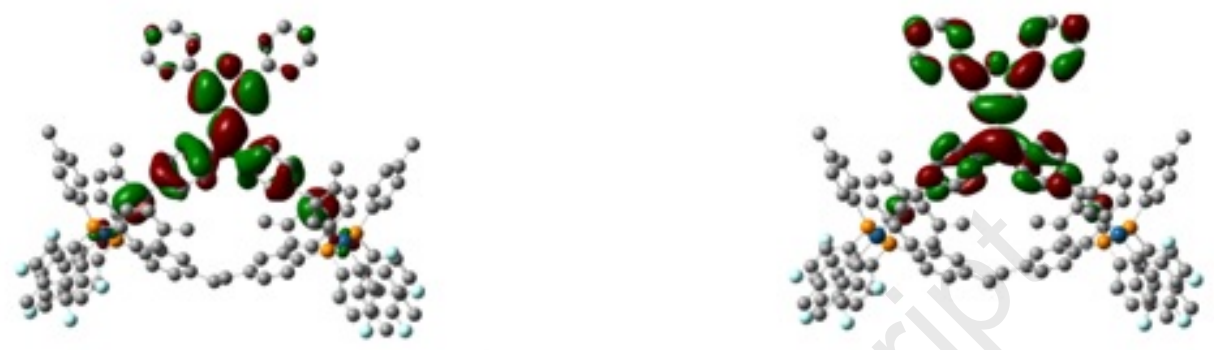

14
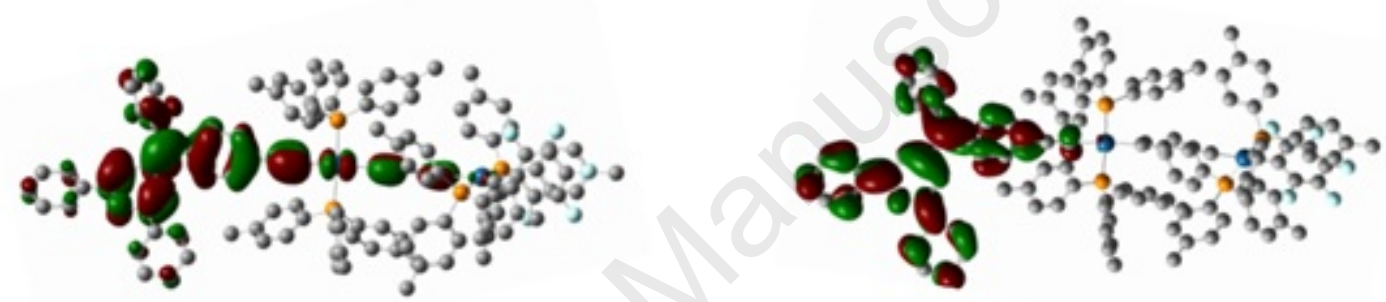

15

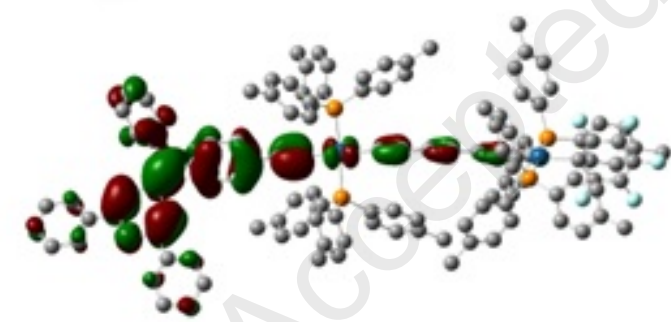

Hомо

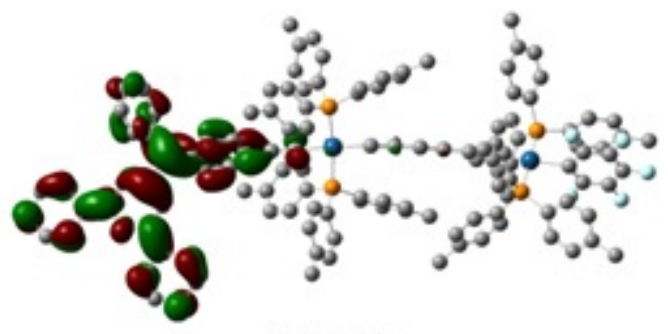

LUMO

Figure 5: CAM-B3LYP frontier orbitals for the investigated systems. From top to bottom: 9, 10, 14, and 15. Hydrogen atoms omitted for clarity. 


\section{CONCLUSION}

We have synthesized a series of new mono- and diplatinum polyynediyl complex chromophores end-capped with diphenylpyranylidene and pentafluorophenyl moieties.The photophysical and electrochemical properties of the complexes substantiated by their theoretical (TD-)DFT studies indicate that they display adequate opto-electronic characteristics and consequently potential as NLO chromophores. Unexpectedly, the inductive electron-withdrawing pentafluorophenyl ligand of these platinum polyynediyl complexes seem to have a much weaker impact on the electronic properties than the mesomeric acceptors in analogous "push-pull”" structures, as shown by the relatively low NLO responses and theoretical results. All investigated complexes display a positive $\mu \beta$. Similar NLO responses obtained for complexes (9, 14 and 15) with polyyne linkers of various lengths show that increasing the length of these linkers does not systematically yield larger NLO responses in such complexes. However, the shape of the complex is important, as shown by the V-shaped complex 10 exhibiting the highest $\mu \beta$ value of the series of complexes, twice as high as that of the linear complex $\mathbf{9}$, due to an adequate arrangement of the individual dipolar contributions. Experiments are currently underway to vary the components of the promising V-shaped complex 10 with different mesomeric acceptor groups (malononitrile, indane-1,3-dione, pyrimidine or pyrimidinium) to enhance the charge transfer in these systems and consequently improve the NLO responses. 


\section{EXPERIMENTAL SECTION}

General Methods. NMR spectra were acquired at room temperature on a Bruker AC-300 spectrometer $\left({ }^{1} \mathrm{H}\right.$ at $300 \mathrm{MHz},{ }^{13} \mathrm{C}$ at $75 \mathrm{MHz},{ }^{31} \mathrm{P}$ at $121 \mathrm{MHz},{ }^{19} \mathrm{~F}$ at $\left.282 \mathrm{MHz}\right)$ and referenced as follows: ${ }^{1} \mathrm{H}$ NMR, residual $\mathrm{CHCl}_{3}(\delta=7.26 \mathrm{ppm}) ;{ }^{13} \mathrm{C}\left\{{ }^{1} \mathrm{H}\right\} \mathrm{NMR}$, internal $\mathrm{CDCl}_{3}(\delta=77.16 \mathrm{ppm}) ;{ }^{31} \mathrm{P}\left\{{ }^{1} \mathrm{H}\right\}$ NMR, external $\mathrm{H}_{3} \mathrm{PO}_{4}(\delta=0.00 \mathrm{ppm})$. The chemical shifts $\delta$ are reported in parts per million relative to TMS $\left({ }^{1} \mathrm{H}, 0.0 \mathrm{ppm}\right)$ and $\mathrm{CDCl}_{3}\left({ }^{13} \mathrm{C}, 77.16 \mathrm{ppm}\right)$. The coupling constant $J$ is given in Hz. In the ${ }^{1} \mathrm{H}$ NMR spectra, the following abbreviations are used to describe the peak pattern: s (singlet), $d$ (doublet), dd (doublet of doublet), $t$ (triplet), and $\mathrm{m}$ (multiplet). Acidic impurities in $\mathrm{CDCl}_{3}$ were removed by treatment with anhydrous $\mathrm{K}_{2} \mathrm{CO}_{3}$. IR spectra were recorded on a Perkin-Elmer spectrum 100 spectrometer with an ATR sampling accessory. UV-visible spectra were recorded on a Perkin-Elmer Lambda 25 spectrometer using standard $10 \mathrm{~mm}$ quartz cells. High resolution mass analyses using a Bruker MicroTOFQ II apparatus and Elemental analyses using a Microanalyseur Flash EA1112 CHNS/O Thermo Electron were performed at the “Centre Régional de Mesures Physiques de l'Ouest” (CRMPO, University of Rennes 1). Column chromatographies were performed using silica gel Acros SI 60 (60-200 mesh ASTM). Thin-layer chromatography (TLC) was carried out on EMD Silica Gel $60 \mathrm{~F}_{254}$ (Merck) was visualized with 365 nm UV light.

X-ray Structure Determination. Diffraction data for complex 9 (CCDC 1831483) were collected at $150(2) \mathrm{K}$ using a Bruker APEX CCD diffractometer with graphitemonochromated Mo Ka radiation $(\lambda=0.71073 \AA$ ). The crystallographic data for complex 14 (CCDC 1831485) was collected on a Bruker D8 VENTURE CCD diffractometer equipped with a multilayer monochromator device (Mo Ka radiation, $\lambda=0.71073 \AA$ ). Crystal structures were solved by dual-space algorithm using the SHELXT program, ${ }^{35 a}$ and then refined with full-matrix least-square methods based on $\mathrm{F}^{2}$ (SHELXL-2014). ${ }^{35 \mathrm{~b}}$ All non hydrogen atoms were refined with anisotropic atomic displacement parameters. $\mathrm{H}$ atoms were finally included in the structural model in their calculated positions, and constrained to ride on the attached carbon atom. In the case of $\mathbf{9}$, the contribution of the disordered solvents to the structure facture factors was calculated by the PLATON/SQUEEZE procedure ${ }^{35 c}$ and then taken into account in the final SHELXL-2014 least-squares refinement. Relevant collection and refinement data for all compounds are given in the Supporting Information. All data can be obtained from the Cambridge Structural Database via www.ccdc.cam.ac.uk/data_request/cif. 
Electrochemical Measurements. The electrochemical studies were performed in a glovebox (Jacomex) $\left(\mathrm{O}_{2}<1 \mathrm{ppm}, \mathrm{H}_{2} \mathrm{O}<1 \mathrm{ppm}\right)$ with a home-made 3-electrode cell (WE: Pt, RE: Ag wire, CE: Pt). Ferrocene was added at the end of each experiment to determine the redox potential values. The standard potential of the $\mathrm{Fc}^{+} / \mathrm{Fc}$ couple in $\mathrm{CH}_{2} \mathrm{Cl}_{2} / \mathrm{NBu}_{4} \mathrm{PF}_{6}$ was measured experimentally with reference to the standard calomel electrode (SCE): $E^{0}\left(\mathrm{Fc}^{+} / \mathrm{Fc}\right)$ $=0.47 \mathrm{~V}$ vs. SCE, and recalibrated vs. NHE assuming that $E^{0}(\mathrm{SCE})=0.24 \mathrm{~V}$ vs. NHE. The potential of the cell was controlled by an AUTOLAB PGSTAT 100 (Metrohm) potentiostat monitored by the NOVA ${ }^{\odot}$ software (Metrohm). Dichloromethane was freshly distilled from $\mathrm{CaH}_{2}$ and kept under $\mathrm{Ar}$ in the glovebox. The supporting salt $\mathrm{NBu}_{4} \mathrm{PF}_{6}$ was synthesized from $\mathrm{NBu}_{4} \mathrm{OH}$ (Fluka) and $\mathrm{HPF}_{6}$ (Aldrich). It was then purified, dried under vacuum for 48 hours at $100^{\circ} \mathrm{C}$, and then kept under $\mathrm{N}_{2}$ in the glovebox.

Computational Details. The ground state geometries of all compounds were optimized at DFT level of theory with the M06 ${ }^{36}$ functional combined with the LanL2DZ atomic basis set and pseudopotential, completed with additional functions on all non-hydrogen atoms ( $d$ functions of $\alpha=0.587,0.961,1.577$ and 0.364 for $\mathrm{C}, \mathrm{O}, \mathrm{F}$ and $\mathrm{P}$, respectively and $f$ function of $\alpha=0.993$ for Pt.). During our calculations, we imposed a tight convergence threshold of 1 x $10^{-10}$ a.u. on the SCF energies and we used the so-called ultrafine integration grid [pruned (99590) grid]. TD-DFT calculations and simulation of the non-linear optical properties were performed using the CAM-B3LYP ${ }^{37}$ and $\omega \mathrm{B} 97 \mathrm{X}-\mathrm{D}^{38}$ range-separated hybrid functionals, respectively. These choices are justified because the former functional provides accurate charge-transfer parameters, whereas the latter presents a correct asymptotic behavior, which is needed to obtain accurate NLO properties. The same atomic basis sets as in the optimization step was applied. Bulk solvation effects have been quantified by the Polarizable Continuum Model (PCM), ${ }^{39}$ with dichloromethane as solvent for optimization and TD-DFT calculations and chloroform as solvent for the nonlinear optical properties calculations. For the TD-DFT part, we applied the linear response (LR-PCM) model in its non-equilibrium limit, which is suited for absorption spectra. ${ }^{40}$ All our calculations were carried out with the latest version of the Gaussian 16 program package. ${ }^{41}$

Materials. All reactions were conducted under a dry nitrogen atmosphere using Schlenk techniques, but workups were carried out in air. The starting materials were purchased from Sigma-Aldrich, TCI or Alfa-Aesar and were used as received. The solvents were used as received except tetrahydrofuran that was distilled under a dry nitrogen atmosphere over 
sodium and benzophenone. Compounds 4, 6, 8, 11, 12 and 13 were obtained according to reported procedures. ${ }^{14,19 \mathrm{~d}, 20 \mathrm{~d}}$

Syntheses. Compound 5. A Schlenk flask was charged with tributyl(2,6-dithiophen-4Hpyran-4-yl)phosphonium tetrafluoroborate (615 mg, $1.15 \mathrm{mmol}$ ), $30 \mathrm{~mL}$ of anhydrous THF and $n$-BuLi in hexane solution $(0.5 \mathrm{~mL}, 1.16 \mathrm{mmol})$ at $-78^{\circ} \mathrm{C}$ under argon protection. The solution was stirred at $-78^{\circ} \mathrm{C}$ for $15 \mathrm{~min}$ and bis-(4-(2-trimethylsilylethynyl))benzophenone (450 mg, $1.15 \mathrm{mmol})$ dissolved in dry THF $(10 \mathrm{~mL})$ was added dropwise. The solution was stirred at $-78^{\circ} \mathrm{C}$ under argon $30 \mathrm{~min}$ and then moved to room temperature and stirred overnight. After the reaction, the solvent was removed by rotary evaporation. The residue was purified by column chromatography on silica gel (hexane/dichloromethane $=5 / 1$ ) to give 5 . Yield: 490 mg (yellow solid), 72\%.

IR (ATR, cm $\left.{ }^{-1}\right) 2152\left(v_{\mathrm{C}=\mathrm{C}}\right), 1660,1597,1492\left(v_{\mathrm{C}=\mathrm{C}}\right), 1250\left(v_{\mathrm{C}-\mathrm{o}}\right)$. NMR ( $\left.\delta(\mathrm{ppm}), \mathrm{CDCl}_{3}\right)$ : ${ }^{1} \mathrm{H}(300 \mathrm{MHz}): 7.70-7.60$ (m, 4H), 7.45 (d, $\left.{ }^{3} J_{\mathrm{HH}}=8.2 \mathrm{~Hz}, 4 \mathrm{H}\right), 7.42-7.34$ (m, 6H), 7.19 (d, $\left.{ }^{3} J_{\mathrm{HH}}=8.3 \mathrm{~Hz}, 4 \mathrm{H}\right), 6.68(\mathrm{~s}, 2 \mathrm{H}), 0.28$ (s, 18H). ${ }^{13} \mathrm{C}\left\{{ }^{1} \mathrm{H}\right\}(75 \mathrm{MHz}): 1512.14,142.57,133.43$, 132.15, 130.53, 129.31, 128.74, 127.76, 124.81, 124.76, 124.63, 121.16, 105.41, 105.01, 94.79, 0.17. Anal. Calcd for $\mathrm{C}_{40} \mathrm{H}_{38} \mathrm{OSi}_{2}$ : C, 81.30; H, 6.48. Found: C, 81.42; H, 6.40. HRMS (ESI): m/z, calculated for $\mathrm{M}^{+\bullet}\left(\mathrm{C}_{40} \mathrm{H}_{38} \mathrm{OSi}_{2}\right)$ : 590.2461, found: 590.2458.

Compound 7. In a round bottom flask, to a methanol $(10 \mathrm{~mL})$ and dichloromethane $(20 \mathrm{~mL})$ solution of compound 5 (507 mg, $1.0 \mathrm{mmol}$ ) was added $\mathrm{K}_{2} \mathrm{CO}_{3}(550 \mathrm{mg}, 4.0 \mathrm{mmol}$ ), and the reaction mixture was stirred at room temperature overnight. Deionized water was used to quench the reaction; dichloromethane was added to extract the product. The organic layer as dried over $\mathrm{MgSO}_{4}$, filtered and the solvent was removed under reduced pressure. The residue was purified by column chromatography on silica gel (hexane/dichloromethane $=5 / 1$ ) to give 7. Yield: 420 mg (orange solid), 94\%.

IR $\left(A T R, \mathrm{~cm}^{-1}\right) 3285\left(v_{\equiv \mathrm{C}-\mathrm{H}}\right), 2106\left(v_{\mathrm{C} \equiv \mathrm{C}}\right), 1653,1599,1491\left(v_{\mathrm{C}=\mathrm{C}}\right), 1237\left(v_{\mathrm{C}-\mathrm{O}}\right)$. NMR $(\delta$ (ppm), $\left.\mathrm{CDCl}_{3}\right):{ }^{1} \mathrm{H}(300 \mathrm{MHz}): 7.74-7.61(\mathrm{~m}, 4 \mathrm{H}), 7.50\left(\mathrm{~d},{ }^{3} J_{\mathrm{HH}}=7.9 \mathrm{~Hz}, 4 \mathrm{H}\right), 7.46-7.36$ (m, 6H), 7.25 (d, $\left.{ }^{3} \mathrm{~J}_{\mathrm{HH}}=8.1 \mathrm{~Hz}, 4 \mathrm{H}\right), 6.70$ (s, 2H), 3.15 (s, 2H). ${ }^{13} \mathrm{C}\left\{{ }^{1} \mathrm{H}\right\}(75 \mathrm{MHz}): 152.22$, 142.82, 133.37, 132.33, 130.58, 129.33, 128.73, 127.87, 124.82, 124.27, 120.17, 104.87, 83.95, 77.67. Anal. Calcd for $\mathrm{C}_{34} \mathrm{H}_{22} \mathrm{O}$ : C, 91.45; H, 4.97. Found: C, 91.12; H, 4.97. HRMS (ESI): m/z, calculated for $\mathrm{M}^{+\bullet}\left(\mathrm{C}_{34} \mathrm{H}_{22} \mathrm{O}\right)$ : 446.1671, found: 446.1679. 
Complex 9. A $100 \mathrm{ml}$ Schlenk flask, charged with 6 (152 mg, 0.36 mmol), trans$\left(\mathrm{C}_{6} \mathrm{~F}_{5}\right)\left(\mathrm{Tol}_{3} \mathrm{P}\right)_{2} \mathrm{PtCl} 8$ (300 mg, $\left.0.30 \mathrm{mmol}\right)$, and cuprous iodide (5.7 mg, $10 \mathrm{~mol} \%$ ), was degassed and back-filled with argon three times. Then diethylamine $(20 \mathrm{~mL})$ and dried THF $(10 \mathrm{~mL})$ were introduced into the reaction flask by syringe. The reaction mixture was stirred under argon protection at room temperature for $12 \mathrm{~h}$. The solvent was then removed under reduced pressure. The residue was purified by column chromatography on silica gel (dichloromethane/petroleum ether $1 / 2$ ) and recrystallized by layer-layer diffusion in $\mathrm{CH}_{2} \mathrm{Cl}_{2} / \mathrm{n}$-pentane to give $\mathbf{9}$ as yellow needles. Yield: $315 \mathrm{mg}, 75 \%$.

IR (ATR, cm $\left.{ }^{-1}\right) 2129\left(v_{\mathrm{C} \equiv \mathrm{C}}\right), 1656,1599,1494,1450\left(v_{\mathrm{C}=\mathrm{C}}\right), 1277\left(v_{\mathrm{C}-\mathrm{O}}\right)$. NMR $(\delta(\mathrm{ppm})$, $\left.\mathrm{CDCl}_{3}\right):{ }^{1} \mathrm{H}$ (300 MHz): 7.72 - 7.53 (m, 16H), 7.45 - 7.27 (m, 8H), $7.24-7.15$ (m, 3H), 7.11 $\left(\mathrm{d},{ }^{3} J_{\mathrm{HH}}=7.8 \mathrm{~Hz}, 12 \mathrm{H}\right), 6.77\left(\mathrm{~d},{ }^{3} J_{\mathrm{HH}}=8.3 \mathrm{~Hz}, 2 \mathrm{H}\right), 6.63\left(\mathrm{~d},{ }^{4} J_{\mathrm{HH}}=2.0 \mathrm{~Hz}, 1 \mathrm{H}\right), 6.55\left(\mathrm{~d},{ }^{4} J_{\mathrm{HH}}\right.$ $=2.0 \mathrm{~Hz}, 1 \mathrm{H}), 6.26\left(\mathrm{~d},{ }^{3} J_{\mathrm{HH}}=8.2 \mathrm{~Hz}, 2 \mathrm{H}\right), 2.35$ (s, 18H). ${ }^{13} \mathrm{C}\left\{{ }^{1} \mathrm{H}\right\}$ and JMOD $(75 \mathrm{MHz})$ : 151.14 (C), 151.05 (C), 145.92 (dd, ${ }^{1} J_{\mathrm{CF}}=215.5 \mathrm{~Hz},{ }^{2} J_{\mathrm{CF}}=19.1 \mathrm{~Hz}, o$ to Pt, (C)), 142.63 (C), 140.53 (C), 138.43 (C), 134.57 (virtual t, ${ }^{2} J_{\mathrm{CP}}=6.4 \mathrm{~Hz},{ }^{42}$ o to $\mathrm{P},(\mathrm{CH})$ ), 133.87 (C), 133.81 (C), $130.70(\mathrm{CH}), 130.63(\mathrm{CH}), 129.27(\mathrm{CH}), 128.89(\mathrm{CH}), 128.60$ (virtual t, ${ }^{3} J_{\mathrm{CP}}=5.9 \mathrm{~Hz},{ }^{42}$ $m$ to P, (CH)), $128.43(\mathrm{C}), 128.29(\mathrm{CH}), 128.04$ (virtual t, ${ }^{1} J_{\mathrm{CP}}=29.6 \mathrm{~Hz},{ }^{42} i$ to $\mathrm{P},(\mathrm{C})$ ), 127.20 (C), 126.76 (C), 126.48 (CH), 125.66 (C), 124.77 (CH), $124.67(\mathrm{CH}), 114.70(\mathrm{C})$, $105.42(\mathrm{CH}), 105.34(\mathrm{CH}), 21.48\left(\mathrm{CH}_{3}\right) .{ }^{43}{ }^{31} \mathrm{P}(121 \mathrm{MHz}): 17.61\left(\mathrm{~s},{ }^{1} J_{\mathrm{PtP}}=2691 \mathrm{~Hz}\right) .{ }^{44}$ ${ }^{19} \mathrm{~F}\{1 \mathrm{H}\}(282 \mathrm{MHz}):-117.53\left(\mathrm{~m},{ }^{3} J_{\mathrm{F}, \mathrm{Pt}}=291.3 \mathrm{~Hz}, 2 \mathrm{~F}, o\right.$ to Pt), $-165.66(\mathrm{~m}, 2 \mathrm{~F}, m$ to Pt), $166.42\left(\mathrm{t},{ }^{3} J_{\mathrm{F}, \mathrm{F}}=19.7 \mathrm{~Hz}, 1 \mathrm{~F}, p\right.$ to Pt). Anal. Calcd for $\mathrm{C}_{80} \mathrm{H}_{63} \mathrm{OF}_{5} \mathrm{P}_{2} \mathrm{Pt}$ : C, 69.01; H, 4.56. Found: C, 69.17; $\mathrm{H}$, 4.59. HRMS (ESI): $\mathrm{m} / \mathrm{z}$, calculated for $\mathrm{M}^{+\bullet}\left(\mathrm{C}_{80} \mathrm{H}_{63} \mathrm{OF}_{5} \mathrm{P}_{2}{ }^{195} \mathrm{Pt}\right)$ : 1391.392, found: 1391.390 .

Complex 10. A $100 \mathrm{ml}$ Schlenk flask, charged with 7 (67 mg, $0.15 \mathrm{mmol})$, trans$\left(\mathrm{C}_{6} \mathrm{~F}_{5}\right)\left(\mathrm{Tol}_{3} \mathrm{P}\right)_{2} \mathrm{PtCl} 8$ (300 mg, $\left.0.30 \mathrm{mmol}\right)$, and cuprous iodide (5.7 mg, $10 \mathrm{~mol} \%$ ), was degassed and back-filled with argon three times. Then diethylamine (20 mL) and dried THF $(10 \mathrm{~mL})$ were introduced into the reaction flask by syringe. The reaction mixture was stirred under argon protection at room temperature overnight. The solvent was then removed under reduced pressure. The residue was purified by column chromatography on silica gel (dichloromethane/petroleum ether 1/1) and recrystallized by layer-layer diffusion in $\mathrm{CH}_{2} \mathrm{Cl}_{2} / \mathrm{n}$-pentane to give $\mathbf{1 0}$ as orange needles. Yield: $250 \mathrm{mg}, 70 \%$. 
IR (ATR, cm $\left.{ }^{-1}\right) 2115\left(v_{\mathrm{C}=\mathrm{C}}\right), 1661,1599,1498,1449\left(v_{\mathrm{C}=\mathrm{C}}\right), 1283\left(v_{\mathrm{C}-\mathrm{O}}\right)$. NMR $(\delta(\mathrm{ppm})$, $\left.\mathrm{CDCl}_{3}\right):{ }^{1} \mathrm{H}(300 \mathrm{MHz}): 7.67-7.46(\mathrm{~m}, 28 \mathrm{H}), 7.41-7.28(\mathrm{~m}, 6 \mathrm{H}), 7.10\left(\mathrm{~d},{ }^{3} \mathrm{~J}_{\mathrm{HH}}=7.7 \mathrm{~Hz}\right.$, 24H), $6.65\left(\mathrm{~d},{ }^{3} J_{\mathrm{HH}}=8.2 \mathrm{~Hz}, 4 \mathrm{H}\right), 6.49(\mathrm{~s}, 2 \mathrm{H}), 6.19\left(\mathrm{~d},{ }^{3} J_{\mathrm{HH}}=8.3 \mathrm{~Hz}, 4 \mathrm{H}\right), 2.34(\mathrm{~s}, 36 \mathrm{H})$. ${ }^{13} \mathrm{C}\left\{{ }^{1} \mathrm{H}\right\}$ and JMOD (75 MHz): $150.75(\mathrm{C}), 146.22$ (dm, ${ }^{1} J_{\mathrm{CF}}=222.6 \mathrm{~Hz}, o$ to Pt, (C)), 140.51 (C), 138.53 (C), 134.58 (virtual t, ${ }^{2} J_{\mathrm{CP}}=6.3 \mathrm{~Hz},{ }^{42} o$ to P, (CH)), $133.91(\mathrm{C}), 130.48(\mathrm{CH})$, $129.38(\mathrm{CH}), 128.60$ (virtual $t,{ }^{3} J_{\mathrm{CP}}=5.5 \mathrm{~Hz},{ }^{42} \mathrm{~m}$ to P, $(\mathrm{CH})$ ), 128.05 (virtual t, ${ }^{1} J_{\mathrm{CP}}=29.6$ $\mathrm{Hz},{ }^{42} i$ to P, (C)), 127.27 (C), 127.09 (C), 125.07 (C), 124.68 (CH), 114.72 (C), 112.22 (C), $105.69(\mathrm{CH}), 21.49\left(\mathrm{CH}_{3}\right) .{ }^{43}{ }^{31} \mathrm{P}(121 \mathrm{MHz}): 17.59\left(\mathrm{~s},{ }^{1} J_{\mathrm{PtP}}=2692 \mathrm{~Hz}\right) .{ }^{44}{ }^{19} \mathrm{~F}\{1 \mathrm{H}\}(282$ $\mathrm{MHz}):-117.53\left(\mathrm{~m},{ }^{3} J_{\mathrm{F}, \mathrm{Pt}}=291.3 \mathrm{~Hz}, 2 \mathrm{~F}, o\right.$ to Pt), -165.66 (m, 2F, $m$ to Pt), $-166.42\left(\mathrm{t},{ }^{3} J_{\mathrm{F}, \mathrm{F}}\right.$ $=19.7 \mathrm{~Hz}, 1 \mathrm{~F}, p$ to $\mathrm{Pt}$ ). Anal. Calcd for $\mathrm{C}_{130} \mathrm{H}_{104} \mathrm{OF}_{10} \mathrm{P}_{4} \mathrm{Pt}_{2}$ : C, 65.43; H, 4.39. Found: $\mathrm{C}$, 65.17; H, 4.30. HRMS (ESI): $\mathrm{m} / \mathrm{z}$, calculated for $\mathrm{M}^{+\bullet}\left(\mathrm{C}_{130} \mathrm{H}_{104} \mathrm{OF}_{10} \mathrm{P}_{4}{ }^{195} \mathrm{Pt}_{2}\right): 2384.617$, found: 2384.621 .

Complex 14. A $100 \mathrm{ml}$ Schlenk flask, charged with chloro complex 11 (360 mg, 0.28 mmol), trans $-\left(\mathrm{C}_{6} \mathrm{~F}_{5}\right)\left(\mathrm{Tol}_{3} \mathrm{P}\right)_{2} \mathrm{Pt}(\mathrm{C} \equiv \mathrm{C})_{2} \mathrm{H} 12$ (292 mg, $\left.0.28 \mathrm{mmol}\right)$, and cuprous iodide (5.4 mg, 10 mol\%), was degassed and back-filled with argon three times. Then diethylamine $(20 \mathrm{~mL})$ and dried THF (10 mL) were introduced into the reaction flask by syringe. The reaction mixture was stirred under argon protection at room temperature for 48h. The solvent was then removed under reduced pressure. The residue was purified by column chromatography on silica gel (dichloromethane/petroleum ether 1/1) and recrystallized by layer-layer diffusion in $\mathrm{CHCl}_{3} / \mathrm{n}$-pentane to give $\mathbf{1 4}$ as yellow needles. Yield: $450 \mathrm{mg}, 72 \%$.

IR (ATR, cm $\left.{ }^{-1}\right) 2118\left(v_{\mathrm{C}=\mathrm{C}}\right), 1652,1599,1498,1454\left(v_{\mathrm{C}=\mathrm{C}}\right), 1279\left(v_{\mathrm{C}-\mathrm{O}}\right)$. NMR $(\delta(\mathrm{ppm})$, $\left.\mathrm{CDCl}_{3}\right):{ }^{1} \mathrm{H}$ (300 MHz): 7.70 - 7.58 (m, 5H), 7.57 - 7.42 (m, 24H), 7.41- 7.31 (m, 7H), 7.22 $-7.14(\mathrm{~m}, 3 \mathrm{H}), 6.97\left(\mathrm{~d},{ }^{3} J_{\mathrm{HH}}=7.8 \mathrm{~Hz}, 12 \mathrm{H}\right), 6.91\left(\mathrm{~d},{ }^{3} J_{\mathrm{HH}}=7.8 \mathrm{~Hz}, 12 \mathrm{H}\right), 6.73\left(\mathrm{~d},{ }^{3} J_{\mathrm{HH}}=8.3\right.$ $\mathrm{Hz}, 2 \mathrm{H}), 6.61(\mathrm{~s}, 2 \mathrm{H}), 5.98\left(\mathrm{~d},{ }^{3} J_{\mathrm{HH}}=8.3 \mathrm{~Hz}, 2 \mathrm{H}\right), 2.28(\mathrm{~s}, 18 \mathrm{H}), 2.25$ (s, 18H). ${ }^{13} \mathrm{C}\left\{{ }^{1} \mathrm{H}\right\}$ and JMOD (75 MHz): 151.04 (C), 150.97 (C), 146.00 (dd, ${ }^{1} J_{\mathrm{CF}}=223.4 \mathrm{~Hz},{ }^{2} J_{\mathrm{CF}}=22.7 \mathrm{~Hz}, o$ to Pt, (C)), 142.49 (C), 140.35 (C), 140.04 (C), 139.66 (C), 138.15 (C), 135.14 (virtual t, ${ }^{2} J_{\mathrm{CP}}=$ $6.2 \mathrm{~Hz},{ }^{42} o$ to $\mathrm{P},(\mathrm{CH})$ ), 134.60 (virtual t, ${ }^{2} J_{\mathrm{CP}}=6.3 \mathrm{~Hz},{ }^{42} o$ to $\mathrm{P}^{\prime},(\mathrm{CH})$ ), $133.80(\mathrm{C}), 133.77$ (C), 131.06 (CH), 130.62 (CH), 129.38 (C), 129.09 (CH), 128.98 (C), $128.86(\mathrm{CH}), 128.80$ (CH), $128.73(\mathrm{CH}), 128.62(\mathrm{CH}), 128.57(\mathrm{CH}), 128.36$ (virtual t, ${ }^{3} J_{\mathrm{CP}}=5.4 \mathrm{~Hz},{ }^{42} m$ to P; $m$ to P' obscured, $(\mathrm{CH})$ ), $128.21(\mathrm{CH}), 127.88$ (virtual t, ${ }^{1} J_{\mathrm{CP}}=29.3 \mathrm{~Hz},{ }^{42} i$ to $\mathrm{P}$; $i$ to P' obscured, (C)), $126.94(\mathrm{C}), 126.41(\mathrm{CH}), 125.57$ (C), $124.66(\mathrm{CH}), 124.63(\mathrm{CH}), 114.88(\mathrm{C}), 111.90$ (C), $105.50(\mathrm{CH}), 105.33(\mathrm{CH}), 104.20$ (C), 103.16 (C), $93.41(\mathrm{C}), 21.53\left(\mathrm{CH}_{3}\right), 21.37$ 
$\left(\mathrm{CH}_{3}\right) \cdot{ }^{43}{ }^{31} \mathrm{P}(121 \mathrm{MHz}): 16.31\left(\mathrm{~s},{ }^{1} J_{\mathrm{PtP}}=2708 \mathrm{~Hz}\right), 14.69\left(\mathrm{~s},{ }^{1} J_{\mathrm{PtP}}=2627 \mathrm{~Hz}\right) \cdot{ }^{44}{ }^{19} \mathrm{~F}\{1 \mathrm{H}\}(282$ MHz): $-117.23\left(\mathrm{~m},{ }^{3} J_{\mathrm{F}, \mathrm{Pt}}=286.2 \mathrm{~Hz}, 2 \mathrm{~F}, o\right.$ to Pt), $-165.83\left(\mathrm{~m}, 2 \mathrm{~F}, m\right.$ to Pt), $-166.94\left(\mathrm{t},{ }^{3} J_{\mathrm{F}, \mathrm{F}}\right.$ $=19.7 \mathrm{~Hz}, 1 \mathrm{~F}, p$ to $\mathrm{Pt}$ ). Anal. Calcd for $\mathrm{C}_{126} \mathrm{H}_{105} \mathrm{OF}_{5} \mathrm{P}_{4} \mathrm{Pt}_{2}$ : C, 67.43; H, 4.72. Found: C, 67.06; $\mathrm{H}$, 4.63. HRMS (ESI): $\mathrm{m} / \mathrm{z}$, calculated for $\mathrm{M}^{+\bullet}\left(\mathrm{C}_{126} \mathrm{H}_{105} \mathrm{OF}_{5} \mathrm{P}_{4}{ }^{195} \mathrm{Pt}_{2}\right)$ : 2242.6326, found: 2242.6356 .

Complex 15. A $100 \mathrm{ml}$ Schlenk flask charged with trans- $\left(\mathrm{C}_{6} \mathrm{~F}_{5}\right)\left(p \text {-tol }{ }_{3} \mathrm{P}\right)_{2} \mathrm{Pt}(\mathrm{C} \equiv \mathrm{C})_{3} \mathrm{SiEt}_{3} 13$ (375 mg, $0.32 \mathrm{mmol}$ ) and THF (10 mL), was degassed and back-filled with argon three times. Then wet $\mathrm{nBu}_{4} \mathrm{~N}^{+} \mathrm{F}\left(1.0 \mathrm{M}\right.$ in $\left.\mathrm{THF} / 5 \mathrm{wt} \% \mathrm{H}_{2} \mathrm{O}, 0.070 \mathrm{~mL}, 0.070 \mathrm{mmol}\right)$ was added with stirring. After $0.5 \mathrm{~h}$, chloro complex 11 (400 mg, $0.32 \mathrm{mmol}$ ), cuprous iodide (6.1 mg, 10 mol\%), and diethylamine $(20 \mathrm{~mL})$ were introduced into the reaction flask. The reaction mixture was stirred under argon protection at room temperature for $48 \mathrm{~h}$. The solvent was removed under reduced pressure. The residue was purified by column chromatography on silica gel (hexane/dichloromethane: 1/1) to give 15 as a yellow solid. Yield: 550 mg, 76\%.

IR (ATR, cm $\left.{ }^{-1}\right) 2103\left(v_{\mathrm{C} \equiv \mathrm{C}}\right), 1654,1599,1498,1453\left(v_{\mathrm{C}=\mathrm{C}}\right), 1277\left(v_{\mathrm{C}-\mathrm{O}}\right)$. NMR $(\delta(\mathrm{ppm})$, $\left.\mathrm{CDCl}_{3}\right):{ }^{1} \mathrm{H}(300 \mathrm{MHz}): 7.71-7.59(\mathrm{~m}, 16 \mathrm{H}), 7.59-7.49$ (m, 12H), $7.43-7.28$ (m, 8H), $7.24-7.19(\mathrm{~m}, 3 \mathrm{H}), 7.18-7.06(\mathrm{~m}, 24 \mathrm{H}), 6.80\left(\mathrm{~d},{ }^{3} J_{\mathrm{HH}}=8.3 \mathrm{~Hz}, 2 \mathrm{H}\right), 6.65\left(\mathrm{~d},{ }^{4} J_{\mathrm{HH}}=2.0 \mathrm{~Hz}\right.$, $1 \mathrm{H}), 6.63\left(\mathrm{~d},{ }^{4} J_{\mathrm{HH}}=2.0 \mathrm{~Hz}, 1 \mathrm{H}\right), 6.16\left(\mathrm{~d},{ }^{3} J_{\mathrm{HH}}=8.3 \mathrm{~Hz}, 2 \mathrm{H}\right), 2.37(\mathrm{~s}, 18 \mathrm{H}), 2.28(\mathrm{~s}, 18 \mathrm{H})$. ${ }^{13} \mathrm{C}\left\{{ }^{1} \mathrm{H}\right\}$ and JMOD (75 MHz): $151.06(\mathrm{C}), 145.94\left(\mathrm{dm},{ }^{1} J_{\mathrm{CF}}=219.3 \mathrm{~Hz}, o\right.$ to Pt, (C)), 142.50 (C), 140.52 (CH), 140.33 (C), 138.48 (C), 135.00 (virtual t, ${ }^{2} J_{\mathrm{CP}}=6.2 \mathrm{~Hz},{ }^{42} o$ to $\mathrm{P},(\mathrm{CH})$ ), 134.55 (virtual t, ${ }^{2} J_{\mathrm{CP}}=6.4 \mathrm{~Hz},{ }^{42} o$ to $\mathrm{P}^{\prime},(\mathrm{CH})$ ), $133.79(\mathrm{C}), 130.91(\mathrm{CH}), 130.63(\mathrm{CH})$, $129.22(\mathrm{CH}), 128.88(\mathrm{CH}), 128.70(\mathrm{CH}), 128.67(\mathrm{CH}), 128.63(\mathrm{CH}), 128.60$ (virtual t, ${ }^{3} J_{\mathrm{CP}}=$ $5.5 \mathrm{~Hz},{ }^{42} m$ to P'; $m$ to P' obscured, $\left.(\mathrm{CH})\right), 128.53(\mathrm{CH}), 128.28(\mathrm{CH}), 128.24(\mathrm{CH}), 127.86$ (virtual t, ${ }^{1} J_{\mathrm{CP}}=29.9 \mathrm{~Hz},{ }^{42} i$ to P; $i$ to P' obscured, (C)), $126.95(\mathrm{C}), 126.79(\mathrm{C}), 126.45(\mathrm{CH})$, $125.68(\mathrm{C}), 124.70(\mathrm{CH}), 124.65(\mathrm{CH}), 113.31$ (C), $110.79(\mathrm{C}), 105.41(\mathrm{CH}), 105.33(\mathrm{CH})$, 99.08 (C), $96.73(\mathrm{C}), 21.48\left(\mathrm{CH}_{3}\right), 21.45\left(\mathrm{CH}_{3}\right) .{ }^{43}{ }^{31} \mathrm{P}(121 \mathrm{MHz}): 16.97\left(\mathrm{~s},{ }^{1} J_{\mathrm{PtP}}=2668 \mathrm{~Hz}\right)$, $16.70\left(\mathrm{~s},{ }^{1} J_{\mathrm{PtP}}=2596 \mathrm{~Hz}\right) .{ }^{44}{ }^{19} \mathrm{~F}\{1 \mathrm{H}\}(282 \mathrm{MHz}):-117.52\left(\mathrm{~m},{ }^{3} J_{\mathrm{F}, \mathrm{Pt}}=289.6 \mathrm{~Hz}, 2 \mathrm{~F}, o\right.$ to Pt), $-165.65\left(\mathrm{~m}, 2 \mathrm{~F}, m\right.$ to $\mathrm{Pt}$ ), $-166.50\left(\mathrm{t},{ }^{3} J_{\mathrm{F}, \mathrm{F}}=19.5 \mathrm{~Hz}, 1 \mathrm{~F}, p\right.$ to Pt). Anal. Calcd for $\mathrm{C}_{128} \mathrm{H}_{105} \mathrm{OF}_{5} \mathrm{P}_{4} \mathrm{Pt}_{2}$ : C, 67.78; H, 4.67. Found: C, 67.34; H, 4.61. HRMS (ESI): m/z, calculated for $\mathrm{M}^{+\bullet}\left(\mathrm{C}_{128} \mathrm{H}_{105} \mathrm{OF}_{5} \mathrm{P}_{4}{ }^{195} \mathrm{Pt}_{2}\right)$ : 2266.633, found: 2266.615 . 


\section{ASSOCIATED CONTENT}

\section{Supporting Information}

The Supporting Information is available free of charge on the ACS Publications website at DOI:XXX.

X-ray diffraction data for compounds 9 and 14, graphic stick and ball representation of the molecular structure of complex 10, list of xyz Cartesian coordinates for $\mathbf{1 0}$ (x // a cell axis), experimental cyclic voltammograms data for compounds 10 and 15, the spin density of complexes $\mathbf{9}^{+\bullet}$ and $\mathbf{1 0}^{+\bullet}$ and the NMR spectra for all new compounds.

\section{Accession Codes}

CCDC 1831483, 1831485 contain the supplementary crystallographic data for this paper. These data can be obtained free of charge via www.ccdc.cam.ac.uk/data_request/cif, or by emailing data_request@ccdc.cam.ac.uk, or by contacting The Cambridge Crystallographic Data Centre, 12 Union Road, Cambridge CB2 1EZ, UK; fax: +44 1223336033.

\section{AUTHOR INFORMATION}

\section{Corresponding Author:}

*E-mail: sebastien.gauthier@univ-rennes1.fr.

\section{ORCID}

Sébastien Gauthier: 0000-0002-3966-2410

Denis Jacquemin: 0000-0002-4217-0708

Sylvain Achelle: 0000-0002-9226-7735

Niclas Le Poul: 0000-0002-5915-3760

\section{Notes}

The authors declare no competing financial interest.

\section{ACKNOWLEDGMENTS}

We deeply thank Prof. Bertrand Caro for his insightful advices and helpful comments. Ariel Porter would like to thank the Northern Kentucky University (NKU) STEM International Research and Scholarly Exchange Program (IRSEP) for providing her internship and the NKU Center for Global Engagement and International Affairs for financial support. The theoretical calculations use resources of the CCIPL in Nantes and of the IDRIS/CINES in Paris. 


\section{REFERENCES}

(1) Organic Materials for Photonics: Science and Technology, ed. Zerbi, G. Elsevier, Amsterdam, 1993.

(2) Chavan, S. S.; Bharate, B.G. Heterobimetallic M(II)/Ru(II) $(\mathrm{M}=\mathrm{Ni}$, Zn) Complexes Containing Coordination and Organometallic Sites: Synthesis, Characterization, Luminescence and NLO Properties. Inorg. Chim. Acta. 2013, 394, 598-604.

(3) (a) Duncan, T. V.; Frail, P. R.; Miloradovic, I. R.; Therien. M. J. Excitation of Highly Conjugated (Porphinato)palladium(II) and (Porphinato)platinum(II) Oligomers Produces Long-Lived, Triplet States at Unit Quantum Yield That Absorb Strongly over Broad Spectral Domains of the NIR. J. Phys. Chem. B. 2010, 114, 14696-14702. (b) Zhang, H.; Zelmon, D. E.; Deng, L.; Liu, H. K.; Teo, B. K. Optical Limiting Behavior of Nanosized Polyicosahedral Gold-Silver Clusters Based on Third-Order Nonlinear Optical Effects. J. Am. Chem. Soc. 2001, 123, 11300-11301.

(4) Prasad, N. P. and Williams, D. J. Introduction to Nonlinear Optical Effects in molecules and Polymers, Wiley, New York, 1991.

(5) Zyss, J. Molecular Nonlinear Optics: Materials, Physics and Devices; Academic Press: Boston, 1994.

(6) See for example (a) Boixel, J.; Guerchais, V.; Le Bozec, H.; Jacquemin, D.; Amar, A.; Boucekkine, A.; Colombo, A.; Dragonetti, C.; Marinotto, D.; Roberto, D.; Righetto, S.; De Angelis, R. Second-Order NLO Switches from Molecules to Polymer Films Based on Photochromic Cyclometalated Platinum(II) Complexes. J. Am. Chem. Soc. 2014, 136, 5367-5375. (b) Di Bella, S.; Dragonetti, C.; Pizzotti, M.; Roberto, D.; Tessore, F.; Ugo, R. In Molecular Organometallic Materials for Optics; H., Le Bozec, Guerchais, V., Eds.; Topics in Organometallic Chemistry; Springer: Berlin, 2010; Vol. 28, pp 1-55. (c) Maury, O.; Le Bozec, H. In Molecular Materials; Bruce, D. W., O’Hare, D., Walton, R. I., Eds.; Wiley: Chichester, U.K., 2010; pp 1-59. (d) Humphrey, M. G.; Samoc, M. Organotransition Metal Complexes for Nonlinear Optics. Adv. Organomet. Chem. 2008, 55, 61-136.

(e) Cariati, E.; Pizzotti, M.; Roberto, D.; Tessore, F.; Ugo, R. Coordination and Organometallic Compounds and Inorganic-organic Hybrid Crystalline Materials for Second-order Non-linear Optics. Coord. Chem. Rev. 2006, 250, 1210-1233. (f) Lucenti, E.; Cariati, E.; Dragonetti, C.; Manassero L.; Tessore, F. Effect of the Coordination to the "Os $(\mathrm{CO})_{11}$ " Cluster Core on the Quadratic Hyperpolarizability of Trans-4-(4'-X-styryl)pyridines (X = NMe $\left.2, \mathrm{t}-\mathrm{Bu}, \mathrm{CF}_{3}\right)$ and Trans,trans-4-(4'$\mathrm{NMe}_{2}$-phenyl-1,3-butadienyl)pyridine. Organometallics 2004, 23, 687-692.

(7) (a) Xu, X.-D.; Yang, H.-B.; Zheng, Y.-R.; Ghosh, K.; Lyndon, M. M.; Muddiman D. C.; Stang, P. J. Self-Assembly of Dendritic Tris(crown ether) Hexagons and Their Complexation with Dibenzylammonium Cations. J. Org. Chem. 2010, 75, 7373-7380. (b) Tam, A. Y.-Y.; Wong K. M.-C.; Yam, V. W.-W. Unusual Luminescence Enhancement of Metallogels of Alkynylplatinum(II) 2,6Bis(N-alkylbenzimidazol-2'-yl)pyridine Complexes upon a Gel-to-Sol Phase Transition at Elevated 
Temperatures. J. Am. Chem. Soc. 2009, 131, 6253-6260. (c) Scarpaci, A.; Monnereau, C.; Hergue, N.; Blart, E.; Legoupy, S.; Odobel, F.; Gorfo, A.; Perez-Moreno, J.; Clays K.; Asselberghs, I. Preparation and Characterization of Second Order Non-linear Optical Properties of New "Push-pull" Platinum Complexes. Dalton Trans. 2009, 4538-4546. (d) Paul, F.; Lapinte, C. A New Route to Sulfur Polyimido Anions S(NR)nm-: Reactivity and Coordination Behavior. Coord. Chem. Rev. 1998, 178180 (Part 1), 431- 509. (e) Ziessel, R.; Hissler, M.; El-ghayoury A.; Harriman, A.; Multifunctional Transition Metal Complexes. Information Transfer at the Molecular Level. Coord. Chem. Rev. 1998, 178-180 (Part 2), 1251-1298.

(8) Wong, W.-Y.; Harvey, P. D. Recent Progress on the Photonic Properties of Conjugated Organometallic Polymers Built Upon the trans-Bis(para-ethynylbenzene)bis(phosphine)platinum(II) Chromophore and Related Derivatives. Macromol. Rapid Commun. 2010, 31, 671-713.

(9) (a) Zhao, G.-Z.; Li, Q.-J.; Chen, L.-J.; Tan, H.; Wang, C.-H.; Wang, D.-X.; Yang, H.-B. Coordination-Driven Self-Assembly of Neutral Dendritic Multiferrocenyl Hexagons via Oxygen-toPlatinum Bonds and Their Electrochemistry. Organometallics 2011, 30, 5141-5146. (b) Chakrabarty, R.; Mukherjee P. S.; Stang, P. J. Supramolecular Coordination: Self-Assembly of Finite Two- and Three-Dimensional Ensembles. Chem. Rev. 2011, 111, 6810-6918. (c) Ghosh, K.; Hu, J.; White, H. S.; Stang, P. J. Construction of Multifunctional Cuboctahedra via Coordination-Driven Self-Assembly. J. Am. Chem. Soc. 2009, 131, 6695-6697. (d) Ghosh, K.; Yang, H.-B.; Northrop, B. H.; Lyndon, M. M.; Zheng, Y.-R.; Muddiman, D. C.; Stang, P. J. Coordination-Driven Self-Assembly of Cavity-Cored Multiple Crown Ether Derivatives and Poly[2]pseudorotaxanes. J. Am. Chem. Soc. 2008, 130, 53205334.

(10) ( a) Suzuki, S.; Matsumoto, Y.; Tsubamoto, M.; Sugimura, R.; Kozaki, M.; Kimoto, K.; Iwamura, M.; Nozaki, K.; Senju, N.; Uragami, C.; Hashimoto, H.; Muramatsu, Y.; Konno A.; Okada, K. Photoinduced Electron Transfer of Platinum(II) Bipyridine Diacetylides Linked by Triphenylamineand Naphthaleneimide-derivatives and Their Application to Photoelectric Conversion Systems. Phys. Chem. Chem. Phys. 2013, 15, 8088-8094. (b) Du, P.; Knowles, K.; Eisenberg, R. A Homogeneous System for the Photogeneration of Hydrogen from Water Based on a Platinum(II) Terpyridyl Acetylide Chromophore and a Molecular Cobalt Catalyst. J. Am. Chem. Soc. 2008, 130, 1257612577. (c) Jarosz, P.; Du, P.; Schneider, J.; Lee, S.-H.; McCamant, D.; Eisenberg, R. Platinum(II) Terpyridyl Acetylide Complexes on Platinized $\mathrm{TiO}_{2}$ : Toward the Photogeneration of $\mathrm{H}_{2}$ in Aqueous Media. Inorg. Chem. 2009, 48, 9653-9663. (d) Du, P.; Schneider, J.; Jarosz, P.; Zhang, J.; Brennessel, W. W.; Eisenberg, R. Photoinduced Electron Transfer in Platinum(II) Terpyridyl Acetylide Chromophores: Reductive and Oxidative Quenching and Hydrogen Production. J. Phys. Chem. B 2007, 111, 6887-6894. (e) Wadas, T. J.; Chakraborty, S.; Lachicotte, R. J.; Wang, Q.-M.; Eisenberg, R. Facile Synthesis, Structure, and Luminescence Properties of $\operatorname{Pt}($ diimine)bis(arylacetylide) Chromophore-Donor Dyads. Inorg. Chem. 2005, 44, 2628-2638. (f) McGarrah, J. E.; Kim, Y.-J.; 
Hissler, M.; Eisenberg, R. Toward a Molecular Photochemical Device: A Triad for Photoinduced Charge Separation Based on a Platinum Diimine Bis(acetylide) Chromophore. Inorg. Chem. 2001, 40, 4510-4511. (g) Hissler, M.; McGarrah, J. E.; Connick, W. B.; Geiger, D. K.; Cummings, S. D.; Eisenberg, R. Platinum Diimine Complexes: Towards a Molecular Photochemical Device. Coord. Chem. Rev. 2000, 208, 115-137. (h) Chang, C. C.; Pfennig, B.; Bocarsly, A. B. Coord. Photoinduced Multielectron Charge Transfer Processes in Group 8 - Platinum Cyanobridged Supramolecular Complexes. Chem. Rev. 2000, 208, 33-45.

(11) (a) Wu, W.; Zhang, J.; Yang, H.; Jin, B.; Hu, Y.; Hua, J.; Jing, C.; Long, Y.; Tian, H. Narrowing Band Gap of Platinum Acetylide Dye-sensitized Solar Cell Sensitizers with Thiophene $\pi$-bridges. J. Mater. Chem. 2012, 22, 5382-5389. (b) Wu, W.; Xu, X.; Yang, H.; Hua, J.; Zhang, X.; Zhang, L.; Long, Y.; Tian, H. D- $\pi$-M- $\pi$-A Structured Platinum Acetylide Sensitizer for Dye-sensitized Solar Cells. J. Mater. Chem. 2011, 21, 10666-10671.

(12) Leininger, S.; Stang, P. J.; Huang, S. Synthesis and Characterization of Organoplatinum Dendrimers with 1,3,5-Triethynylbenzene Building Blocks. Organometallics 1998, 17, 3981-3987.

(13) (a) Faux, N.; Robin-le Guen, F.; Le Poul, P.; Caro, B.; Nakatani, K.; Ishow, E.; Golhen, S. Synthesis and NLO Properties of 4-(4H-chalcogenopyran-4-ylidene and 4H-chalcogenochromen-4ylidene)-1-(phenylthio)but-2-enylidene Complexes-electronic Influence of the Carbene Fragment. Eur. J. Inorg. Chem. 2006, 17, 3489-3497; (b) Faux, N.; Caro, B.; Robin-Le Guen, F.; Le Poul, P.; Nakatani, K.; Ishow, E. $\gamma$-Methylene Chalcogenapyrans and Benzopyrans as Proaromatic Donors in "Push-pull" Fischer Type Carbene Complexes: Influences of Chalcogen Atom and Chain Length on the Electronic and N.L.O. Properties of these Molecules. J. Organomet. Chem. 2005, 690, 4982-4988.

(14) Gauthier, S.; Caro, B.; Robin-Le Guen, F.; Bhuvanesh, N.; Gladysz, J.A.; Wojcik, L.; Le Poul, N.; Planchat, A.; Pellegrin, Y.; Blart, E.; Jacquemin, D.; Odobel, F. Synthesis, Photovoltaic Performances and TD-DFT Modeling of Push-pull Diacetylide Platinum Complexes in $\mathrm{TiO}_{2}$ Based Dye-sensitized Solar Cells. Dalton. Trans 2014, 43, 11233-11242.

(15) Durand, R. J.; Gauthier, S.; Achelle, S.; Kahlal, S.;. Saillard, J-Y; Barsella, A.; Wojcik, L.; Le Poul, N.; Robin-Le Guen, F. Incorporation of a Platinum Center in the Pi-conjugated Core of Pushpull Chromophores for Nonlinear Optics (NLO). Dalton Trans 2017, 46, 3059-3069.

(16) (a) Kulhánek, J.; Bureš, F.; Pytela, O.; Pippig, F.; Danko, M.; Mikysek, T.; Padělková, Z.; Ludwig, M. Quadrupolar D- $\pi$-A- $\pi$-D Chromophores with Central Tetrafluorobenzene Acceptor and Two Peripheral N,N-dimethylamino and Methoxy Donors. Journal of Fluorine Chemistry 2014, 161, 15-23. (b) Papagni, A.; Maiorana, S.; Del Buttero, P.; Perdicchia, D.; Cariati, F.; Cariati, E.; Marcolli, W. Synthesis and Spectroscopic and NLO Properties of "Push-pull" Structures Incorporating the Inductive Electron-withdrawing Pentafluorophenyl Group. Eur. J. Org. Chem. 2002, 1380-1384.

(17) Li, H.; Yang, L.; Tanga, R.; Hou, Y.; Yang, Y.; Wang, H.; Han, H.; Qin, J.; Li, Q.; Li, Z. Organic Dyes Incorporating N-functionalized Pyrrole as Conjugated Bridge for Dye-sensitized Solar Cells: 
Convenient Synthesis, Additional Withdrawing Group on the $\pi$-bridge and the Suppressed Aggregation. Dyes Pigm. 2013, 99, 863-870.

(18) (a) Lu, Z.; Shao, P.; Li, J.; Hua, J.; Qin, J.; Qin, A.; Ye, C. Two Novel Fluorinated Poly(arylene ether)s with Pendant Chromophores for Second-Order Nonlinear Optical Application. Macromolecules 2004, 37, 7089-7096. (b) Ma, H.; Jen, A. K.-Y.; Dalton, L. R. Polymer-based Optical Waveguides: Materials, Processing, and Devices. Adv. Mater. 2002, 14, 1339-1365. (c) Ma, H.; Wu, J.; Herguth, P.; Chen, B.; Jen, A. K.-Y. Non-lithographic Approach to the Fabrication of Polymeric Nanostructures with a Close-packed 2D Hexagonal Array. Chem. Mater. 2000, 12, 1187-1189.

(19) (a) Zhang, T.; Bhuvanesh, N.; Gladysz, J. A. A Quest for Atropisomerism in Cojoined SquarePlanar Metal Complexes: Synthesis and Structures of Sterically Congested Diplatinum Ethynediyl Adducts. Eur. J. Inorg. Chem. 2017, 1017-1025. (b) Clough, M. C.; Fiedler, T.; Bhuvanesh, N.; Gladysz, J. A. A Phase Based Approach to Insulated Molecular Wires: Diplatinum Octatetraynediyl Complexes Bearing Fluorous Trialkylphosphine Ligands. J. Organomet. Chem. 2016, 812, 34-42. (c) Gauthier, S.; Weisbach, N.; Gladysz, J. A. "Click" Chemistry in Metal Coordination Spheres: Copper(I)-Catalyzed 3+2 Cycloadditions of Benzyl Azide and Platinum Polyynyl Complexes trans$\left(\mathrm{C}_{6} \mathrm{~F}_{5}\right)\left(\mathrm{p}-\mathrm{tol}_{3} \mathrm{P}\right)_{2} \mathrm{Pt}(\mathrm{C} \equiv \mathrm{C})_{\mathrm{n}} \mathrm{H}(\mathrm{n}=2-6)$. Organometallics 2009, 28, 5597-5599. (d) Peters, T. B.; Zheng, Q.; Stahl, J.; Bohling, J. C.; Arif, A. M.; Hampel, F.; Gladysz, J. A. Syntheses and Structures of Monoplatinum Model Complexes for Diplatinum Polyynediyl Adducts $\mathrm{L}_{n} \mathrm{Pt}(\mathrm{C} \equiv \mathrm{C})_{\mathrm{z}} \mathrm{Pt}_{\mathrm{n}}$. J. Organomet. Chem. 2002, 641, 53-61.

(20) (a) Owen, G. R.; Gauthier, S.; Weisbach, N.; Hampel, F.; Bhuvanesh, N.; Gladysz, J. A. Towards Multistranded Molecular Wires: Syntheses, Structures, and Reactivities of Tetraplatinum Bis(polyynediyl) Complexes with Pt- $\mathrm{C}_{\mathrm{x}}-\mathrm{Pt}-\left(\mathrm{P}\left(\mathrm{CH}_{2}\right)_{3} \mathrm{P}\right)_{2}-\mathrm{Pt}-\mathrm{C}_{\mathrm{x}}-\mathrm{Pt}-\left(\mathrm{P}\left(\mathrm{CH}_{2}\right)_{3} \mathrm{P}\right)_{2}$ Cores $(\mathrm{x}=4,6,8)$. Dalton Trans. 2010, 5260-5271. (b) De Quadras, L.; Shelton, A. H.; Kuhn, H.; Hampel, F.; Schanze, K. S.; Gladysz, J. A. Syntheses, Structures, and Electronic and Photophysical Properties of Unsymmetrically Substituted Butadiynediyl and Hexatriynediyl Complexes Derived from $\left(\mathrm{C}_{6} \mathrm{~F}_{5}\right)\left(\mathrm{R}_{3} \mathrm{P}\right)$ ${ }_{2} \mathrm{Pt}$, (p-tol) $\left(\mathrm{R}_{3} \mathrm{P}\right)_{2} \mathrm{Pt}$, and $\left(\mathrm{Ph}_{3} \mathrm{P}\right) \mathrm{Au}$ End-Groups. Organometallics 2008, 27, 4979-4991. (c) Owen, G. R.; Stahl, J.; Hampel, F.; Gladysz, J. A. Syntheses and Structures of Diplatinum Hexatriynediyl Complexes, in Which the sp Carbon Chains Are Shielded by $\mathrm{sp}^{3}$ Carbon Chains. Organometallics 2004, 23, 5889-5892. (d) Mohr, W.; Stahl, J.; Hampel, F.; Gladysz, J. A. Synthesis, Structure, and Reactivity of sp Carbon Chains with Bis(phosphine) Pentafluorophenylplatinum Endgroups: Butadiynediyl (C4) Through Hexadecaoctaynediyl (C16) Bridges, and Beyond. Chem. Eur. J. 2003, 9, 3324-3340.

(21) (a) Stahl, J.; Mohr, W.; De Quadras, L.; Peters, T. B.; Bohling, J. C.; Martín-Alvarez, J. M.; Owen, G. R.; Hampel, F.; Gladysz, J. A. Sp Carbon Chains Surrounded by sp3 Carbon Double Helices: Coordination-Driven Self-Assembly of Wirelike $\mathrm{Pt}(\mathrm{C} \equiv \mathrm{C})_{\mathrm{n}} \mathrm{Pt}$ Moieties That Are Spanned by Two $\mathrm{P}\left(\mathrm{CH}_{2}\right)_{\mathrm{m}} \mathrm{P}$ Linkages. J. Am. Chem. Soc. 2007, 129, 8282-8295. (b) De Quadras, L.; Bauer, E. 
B.; Mohr, W.; Bohling, J. C.; Peters, T. B.; Martín-Alvarez, J. M.; Hampel, F.; Gladysz, J. A. Sp Carbon Chains Surrounded by $\mathrm{sp}^{3}$ Carbon Double Helices: Directed Syntheses of Wirelike $\operatorname{Pt}(\mathrm{C} \equiv \mathrm{C})_{\mathrm{n}} \mathrm{Pt}$ Moieties That Are Spanned by Two $\mathrm{P}\left(\mathrm{CH}_{2}\right)_{\mathrm{m}} \mathrm{P}$ Linkages via Alkene Metathesis. J. Am. Chem. Soc. 2007, 129, 8296-8309. (c) De Quadras, L.; Bauer, E. B.; Stahl, J.; Zhuravlev, F.; Hampel, F.; Gladysz, J. A. sp Carbon Chains Surrounded by sp3 Carbon Double Helices: Wire-like $\operatorname{Pt}(\mathrm{C} \equiv \mathrm{C})_{\mathrm{n}} \mathrm{Pt}$ Moieties that are Spanned by Two $\alpha, \omega$-diphosphines that Bear Heteroatoms or Alkyl Substituents. New. J. Chem. 2007, 31, 1594-1604. (d) De Quadras, L.; Hampel, F.; Gladysz, J. A. Wire-like $\mathrm{PtC} \equiv \mathrm{CC} \equiv \mathrm{CC} \equiv \mathrm{CC} \equiv \mathrm{CPt}$ Moieties Surrounded by Double-helical "insulation": New Motifs Featuring $\mathrm{P}\left(\mathrm{CH}_{2}\right)_{20} \mathrm{P}$ and $\mathrm{P}\left(\mathrm{CH}_{2}\right)_{4} \mathrm{O}\left(\mathrm{CH}_{2}\right)_{2} \mathrm{O}\left(\mathrm{CH}_{2}\right)_{4} \mathrm{P}$ Linkages. Dalton Trans. 2006, 2929-2933. (e) Stahl, J.; Bohling, J. C.; Bauer, E. B.; Peters, T. B.; Mohr, W.; Martín-Alvarez, J. M.; Hampel, F.; Gladysz, J. A. Sp Carbon Chains Surrounded by $\mathrm{sp}^{3}$ Carbon Double Helices: A Class of Molecules that are Accessible by Self-assembly and Models for "Insulated" Molecular-scale Devices. Angew. Chem., Int. Ed. 2002, 41, 1871-1876.

(22) (a) Baranová, Z.; Amini, H.; Bhuvanesh, N.; Gladysz, J. A. Rotaxanes Derived from Dimetallic Polyynediyl Complexes: Extended Axles and Expanded Macrocycles. Organometallics 2014, 33, 6746-6749. (b) Weisbach, N.; Baranová, Z.; Gauthier, S.; Reibenspies, J. H.; Gladysz, J. A. A New Type of Insulated Molecular Wire: a Rotaxane Derived from a Metal-capped Conjugated Tetrayne. Chem. Commun. 2012, 48, 7562-7564.

(23) (a) Owen, G. R.; Stahl, J.; Hampel, F.; Gladysz, J. A. Chem. Eur. J. 2008, 14, 73-87. (b) Zhuravlev, F.; Gladysz, J. A. Electronic Structure and Chain-length Effects in Diplatinum Polyynediyl Complexes Trans,trans-[(X)( $\left.\left.\mathrm{R}_{3} \mathrm{P}\right)_{2} \mathrm{Pt}(\mathrm{C} \equiv \mathrm{C})_{\mathrm{n}} \mathrm{Pt}\left(\mathrm{PR}_{3}\right)_{2}(\mathrm{X})\right]$ : A Computational Investigation. Chem. Eur. J. 2004, 10, 6510-6522.

(24) (a) Bolag, A.; Nishida, J.; Hara, K.; Yamashita, Y. Dye-sensitized Solar Cells Based on Novel Diphenylpyran Derivatives. Chem. Lett. 2011, 40, 510-511. (b) Bolag, A.; Mamada, M.; Nishida, J.I.; Yamashita, Y. Field-Effect Transistors Based on Tetraphenyldipyranylidenes and the Sulfur Analogues. Chem. Mater. 2009, 21, 4350-4352.

(25) Plietzsch, O.; Schade, A.; Hafner, A.; Huuskonen, J.; Rissanen, K.; Nieger, M.; Muller, T.; Bräse, S. Synthesis and Topological Determination of Hexakis-Substituted 1,4-Ditritylbenzene and NonakisSubstituted 1,3,5-Tritritylbenzene Derivatives: Building Blocks for Higher Supramolecular Assemblies. Eur. J. Org. Chem. 2013, 283-299.

(26) The connectivity of complex $\mathbf{1 0}$ is supported by a X-diffraction study, the quality of which prevents its publication, graphic representation of the molecular structure and the list of cartesian coordinates of complex $\mathbf{1 0}$ are given in Figure S21 and Table S3 in the Supporting Information (SI).

(27) Peters, T. B.; Bohling, J. C.; Arif A. M.; Gladysz, J. A. C8 and C12 sp Carbon Chains That Span Two Platinum Atoms: The First Structurally Characterized 1,3,5,7,9,11-Hexayne. Organometallics 1999, 18, 3261-3263. 
(28) (a) Le Bihan, J.-Y.; Faux, N.; Caro, B.; Robin-Le Guen, F.; Le Poul, P. Easy Synthesis of Heterocyclic Carbene Complexes by Activation of Chalcogenopyrones and Benzopyrones to Pyrylium Salts and Subsequent Addition of Carbanion of Methoxy(methyl)pentacarbonyltungsten Carbene Complex. J. Organomet. Chem. 2007, 692, 5517-5522. (b) Caro, B.; Le Poul, P.; Robin-Le Guen, F.; Sénéchal-Tocquer, M.-C.; Saillard, J.-Y.; Kahlal, S.; Ouahab, L.; Golhen, S. 1,2 and 1,6 Additions of Lithium Reagents to $\gamma$-methylenepyran Fischer-type Carbene Complexes; Evolution of the 1,2 and 1,6 Adducts to Unsaturated Carbene Complexes Indirectly Stabilized by a Heteroatom, and to Pyranylidene Carbene Complexes. Eur. J. Org. Chem. 2000, 4, 577-581. (c) Caro, B.; Le Poul, P.; Robin-Le Guen, F.; Sénéchal-Tocquer, M.-C.; Vaisserman, J. Reactivity of Carbanions of Fischer-type Carbene Complexes with Pyrylium Salts. Synthesis of New $\gamma$-methylenepyran Carbene Complexes via an Addition-oxidation-deprotonation Process. Tetrahedron Lett. 1998, 39, 557-560.

(29) Zheng, Q.; Bohling, J. C.; Peters, T. B.; Frisch, A. C.; Hampel, F.; Gladysz, J. A. A Synthetic Breakthrough into an Unanticipated Stability Regime: a Series of Isolable Complexes in which C6, C8, C10, C12, C16, C20, C24, and C28 Polyynediyl Chains Span Two Platinum Atoms. Chem. Eur. J. 2006, 12, 6486-6505.

(30) Ulrich, G.; Barsella, A.; Boeglin, A.; Niu, S.; Ziessel, R. BODIPY-Bridged Push-Pull Chromophores for Nonlinear Optical Applications. ChemPhysChem 2014, 15, 2693-2700.

(31) (a) Thami, T.; Bassoul, P.; Petit, M. A.; Simon, J.; Fort, A.; Barzoukas, M.; Villaeys, A. Highly Polarizable Metallic Complexes for Nonlinear Optics. Cobaltous Complexes of Unsymmetrical Hydrazone Imine Glyoxal Derivatives. J. Am. Chem. Soc. 1992, 114, 915-921. (b) Ledoux, I.; Zyss, J. Influence of the Molecular Environment in Solution Measurements of the Second-order Optical Susceptibility for Urea and Derivatives. Chem. Phys. 1982, 73, 203-213. (c) Singer, K. D.; Garito, A. F. Measurements of Molecular Second Order Optical Susceptibilities Using dc Induced Second Harmonic Generation. J. Phys. Chem. 1981, 75, 3572-3580. (d) Levine, B. F.; Bethea, C. G. Molecular Hyperpolarizabilities Determined from Conjugated and Nonconjugated Organic Liquids. Appl. Phys. Lett. 1974, 24, 445-447.

(32) (a) Achelle, S.; Malval, J.-P.; Aloïse, S.; Barsella, A.; Spangenberg, A.; Mager, L.; Akdas-Kilig, H.; Fillaut, J.-L.; Caro, B.; Robin-le Guen, F. Synthesis, Photophysics and Nonlinear Optical Properties of Stilbenoid Pyrimidine-Based Dyes Bearing Methylenepyran Donor Groups. ChemPhysChem 2013, 14, 2725-2736. (b) Liu, Z.; Ma, J. Effects of External Electric Field and SelfAggregations on Conformational Transition and Optical Properties of Azobenzene-Based D- $\pi$-A Type Chromophore in THF Solution. J. Phys. Chem. A. 2011, 115, 10136-10145.

(33) Nguyen, P.; Lesly, G.; Marder, T. B. Second-Order Nonlinear Optical Properties of Push-Pull Bis(phenylethynyl)benzenes and Unsymmetric Platinum Bis(phenylacetylide) Complexes. Chem. Mat. 1997, 9, 406-408. 
(34) Ciofini, I.; Le Bahers, T.; Adamo, C.; Odobel, F.; Jacquemin, D. Through-Space Charge Transfer in Rod-Like Molecules: Lessons from Theory. J. Phys. Chem. C 2012, 116, 11946-11955.

(35) (a) Sheldrick, G. M. SHELXT - Integrated Space-group and Crystal-structure Determination. Acta Cryst. 2015, A71, 3-8; (b) Sheldrick, G. M. Crystal Structure Refinement with SHELXL. Acta Cryst. 2015, C71, 3-8; (c) Spek, A. L. PLATON SQUEEZE: a Tool for the Calculation of the Disordered Solvent Contribution to the Calculated Structure Factors. Acta Cryst. 2015, C71, 9-18

(36) Zhao, Y.; Truhlar, D. G. The M06 Suite of Density Functionals for Main Group Thermochemistry, Thermochemical Kinetics, Noncovalent Interactions, Excited States, and Transition Elements: Two New Functionals and Systematic Testing of Four M06-class Functionals and 12 Other Functionals. Theor. Chem. Acc. 2008, 120, 215-241.

(37) Yanai, T.; Tew, D. P.; Handy, N. C. A New Hybrid Exchange-correlation Functional Using the Coulomb-attenuating Method (CAM-B3LYP). Chem. Phys. Lett. 2004, 393, 51-57.

(38) Chai, J. D.; Head-Gordon, M. Long-range Corrected Hybrid Density Functionals with Damped Atom-atom Dispersion Corrections. Phys. Chem. Chem. Phys. 2008, 10, 6615-6620.

(39) Tomasi, J.; Mennucci, B.; Cammi, R. Quantum Mechanical Continuum Solvation Models. Chem. Rev. 2005, 105, 2999-3094.

(40) Cammi, R.; Mennucci, B. Linear Response Theory for the Polarizable Continuum Model. J. Chem. Phys. 1999, 110, 9877-9886.

(41) Frisch, M. J.; Trucks, G. W.; Schlegel, H. B.; Scuseria, G. E.; Robb, M. A.; Cheeseman, J. R.; Scalmani, G.; Barone, V.; Petersson, G. A.; Nakatsuji, H.; Li, X.; Caricato, M.; Marenich, A. V.; Bloino, J.; Janesko, B. G.; Gom- perts, R.; Mennucci, B.; Hratchian, H. P.; Ortiz, J. V.; Izmaylov, A. F.; Sonnenberg, J. L.; Williams-Young, D.; Ding, F.; Lipparini, F.; Egidi, F.; Go-ings, J.; Peng, B.; Petrone, A.; Henderson, T.; Ranasinghe, D.; Za- krzewski, V. G.; Gao, J.; Rega, N.; Zheng, G.; Liang, W.; Hada, M.; Ehara, M.; Toyota, K.; Fukuda, R.; Hasegawa, J.; Ishida, M.; Nakajima, T.; Honda, Y.; Kitao, O.; Nakai, H.; Vreven, T.; Throssell, K.; Montgomery, Jr., J. A.; Peralta, J. E.; Ogliaro, F.; Bearpark, M. J.; Heyd, J. J.; Brothers, E. N.; Kudin, K. N.; Staroverov, V. N.; Keith, T. A.; Kobayashi, R.; Normand, J.; Raghavachari, K.; Rendell, A. P.; Burant, J. C.; Iyengar, S. S.; Tomasi, J.; Cossi, M.; Millam, J. M.; Klene, M.; Adamo, C.; Cammi, R.; Ochter- ski, J. W.; Martin, R. L.; Morokuma, K.; Farkas, O.; Foresman, J. B. and Fox. D. J. Gaussian 16 Revision A.03, 2016. Gaussian Inc. Wallingford CT.

(42) Hersh, W. H. False AA'X Spin-spin Coupling Systems in ${ }^{13} \mathrm{C}$ NMR: Examples Involving Phosphorus and a 20-year-old Mystery in off-resonance Decoupling. J. Chem. Educ. 1997, 74, 14851488; the ${ }^{n} J_{\mathrm{CP}}$ values represent the apparent couplings between adjacent peaks of the triplet.

(43) The signals of the ipso- $\mathrm{C}_{6} \mathrm{~F}_{5}$, meta- $\mathrm{C}_{6} \mathrm{~F}_{5}$ and para- $\mathrm{C}_{6} \mathrm{~F}_{5}$ carbon were not observed.

(44) This coupling represents a satellite (d; $\left.{ }^{195} \mathrm{Pt} 33.8 \%\right)$, and is not reflected in the peak multiplicity given. 